\title{
Contemporary performance measurement systems in Central and Eastern Europe: a synthesis of the empirical literature*
}

Adriana Rejc Buhovac, Maja Zaman Groff ${ }^{* *}$

The paper presents a synthesis of contemporary performance measurement systems (PMS) research in Central and Eastern Europe (CEE). The literature review is organized around four determinants of contemporary PMS: multidimensionality, strategic focus, cascading, and alignment between PMS and compensation. Discussion of findings and future research directions are suggested along these four determinants while taking into account different institutional, legislative, and cultural contexts of the CEE countries. The paper delivers tentative implications for management researchers and management accounting researchers to guide future thinking and research on PMS in CEE countries. Finally, relevance of research findings for managers is discussed.

In diesem Artikel wird die Synthese von empirischen Forschungen zu modernen Performance-Mess-Systemen (PMS) in Mittel- und Osteuropa dargestellt. Die Literaturanalyse orientiert sich an vier Determinanten von modernen PMS: Multidimensionalität, strategischer Fokus, Cascading (hierarchische Struktur von Performance Indikatoren), und Verbindung zwischen PMS und Strategie. Die Ergebnisse und zukünftigen Forschungsrichtungen werden unter Berücksichtigung von verschiedenen institutionellen, legislativen und kulturellen Kontexten diskutiert. Damit werden Wege für Managementforscher und Management-Accounting-Forscher im Bereich von Performance-Mess-Systemen in Mittel- und Osteuropa aufgezeigt. Nicht zuletzt enthält der Artikel auch relevante Forschungsergebnisse für Manager.

Key words: contemporary performance measurement systems, Central and Eastern Europe, empirical research, synthesis of research questions, gaps in research

\footnotetext{
Manuscript received: 23.04.2010, accepted 10.11.2011 (2 revisions)

** Adriana Rejc Buhovas, Associate Professor of Management, Faculty of Economics, University of Ljubljana. Main research areas: performance measurement and management control, strategic management. Corresponding address: adriana.rejc.buhovac@ef.uni-lj.si Maria Zaman Groff, Assistant Professor of Accounting and Auditing, Faculty of Economics, University of Ljubljana. Main research areas: performance measurement systems, auditing
} 


\section{Introduction}

In recent years, we have been witnessing rapid growth of the empirical performance measurement literature based on increased concerns about the performance measurement systems' role in enhancing company profitability (see, for example, Banker et al. 2000; Lipe/Salterio 2000; Nørreklit 2000; 2003; Kaplan/Norton 2001; 2004; Said et al. 2003; Ittner et al. 2003b; Braam/Nijssen 2004; Davis/Albright 2004; Papalexandris et al. 2004; De Geuser et al. 2009; Liang/Hou 2006). For years, however, most contributions, both in terms of the contemporary frameworks developed as well as empirical research published, came from the United States (Garrison 1990; Lynch/Cross 1991; Fisher 1992; Kaplan/Norton 1996; Atkinson et al. 1997; Fawcett et al. 1997; Simons 1995; Epstein/Birchard 1999; Merchant/Bruns 1986), the United Kingdom (Keegan et al. 1989; Fitzgerald et al. 1991; Kennerley/Neely 2000; Neely et al. 2001; Tonge et al. 2000; Frigo 2002; Brignall 2002; Butler et al. 1997), and continental Western European countries (Epstein/Manzoni 1998; Bontis et al. 1999; Weber/Schäffer 2001; Ahn 2001; Gehrke/Horvath 2002; Speckbacher et al. 2003; Baraldi/Monolo 2004). Very little is known about research conducted in the Central European and, in particular, Eastern European countries (CEE countries) which are characterized by considerably different institutional, legislative, and cultural contexts. The first objective of this paper is to synthesize empirical literature on contemporary performance measurement systems in CEE countries to guide future research. With an overview of the extant empirical research findings and specific guidance on future research in this field, researchers could get a better understanding of the effectiveness of contemporary PMS in CEE countries.

The growth of privatization, deregulation, international businesses, global competition, and new information and production technology has had special implications for performance measurement in these economies (Jaruga/Ho 2002). In numerous examples, companies from CEE countries enthusiastically introduced contemporary performance measurement frameworks developed for organizational contexts of the Western culture but did not achieve expected results (for discussions on historical, institutional, and cultural differences, see for example, Clark 2000; Illes/Rees 2001; Otte 2003; Warner et al. 2005). In other cases, multinational companies were spreading their operations throughout the world and implementing standardized performance measurement and reward systems worldwide, including the CEE countries (Butler et al. 1997; Bontis et al. 1999; Weber/Schäffer 2001; Ahn 2001; Gehrke/Horvath 2002; Otte 2003; Bescos/Cauvin 2004). The second objective of the paper is to build on the research findings to provide guidance on effective PMS implementation to both, managers from non-CEE region considering starting activities in CEE countries, and CEE managers adopting contemporary PMS concepts originating from nonCEE countries. 
From a historical and cultural perspective, the Central European countries comprise the Czech Republic, Hungary, Poland, Slovakia, and Slovenia (Warner et al. 2005). In the CEE group, we also include Albania, Bosnia and Herzegovina, Bulgaria, Croatia, Estonia, Latvia, Lithuania, Macedonia, Montenegro, Romania, and Serbia (OECD List of CEE Countries, 2010). To organize our review, we focus on four determinants of contemporary performance measurement systems that contribute to PMS effectiveness multidimensionality, strategic focus, cascading, and alignment between PMS and compensation (Kaplan/Norton 1996; 2001; 2004; Keegan et al. 1989; Fitzgerald et al. 1991; Lynch/Cross 1991; Atkinson et al. 1997; Neely et al. 2001). The literature synthesis is based on empirical studies published in English in academic journals and well established research conferences or books in the field. More specifically, journals and conference proceedings in management accounting, performance measurement, and management have been reviewed. The cut-off year for contemporary research in selected countries has been set to 1990 which is marked by the German unification in October that year and the subsequent collapse of the communist regimes. Only studies published from 1990 onwards have been considered. The synthesis of the PMS literature excludes studies of the public sector performance measurement. In very few examples, however, the samples of studied companies include some state-owned enterprises.

In the next section, we provide background on contemporary PMS and their role in enhancing company performance. We discuss the four determinants of contemporary PMS to guide the subsequent literature synthesis (in section 3) and a discussion of future research directions in light of underlying different institutional, legislative, and cultural characteristics of CEE countries (in section 4). Section 5 provides implications for managers and section 6 concludes with the limitations of the study.

\section{Determinants of contemporary performance measurement systems}

Performance measurement is closely related to the management control concepts of the English-speaking world and the 'controlling' concepts in German-speaking areas. The underlying aim behind these concepts is to steer or influence the behaviour of members of an organization in such a way as to increase the likelihood of achieving goals (Flamholtz 1996). Anthony's classic definition (Otley et al. 1995) of management control defines it as "the process by which managers assure that resources are obtained and used effectively and efficiently in the accomplishment of the organization's objectives" (Anthony 1965). The term management control systems refers to the set of procedures and processes that managers and other organizational participants use in order to help ensure the achievement of their goals and the goals of their organizations 
(Otley/Berry 1994). It encompasses formal control systems as well as informal personal and social controls.

Performance measurement systems (PMS), the focus of our research, on the other hand, are considered components of managerial accounting and management control systems (Horváth et al. 1999) with a special focus on setting the direction (facilitating strategy development), making (strategic) decisions, and achieving desired goals (Anthony/Govindarajan 1998; Simons 1990; 2000; Ittner/Larcker 1997). More specifically, PMS are formal, information-based routines and procedures managers use to maintain or alter patterns in organizational activities (Simons 1995). Contemporary PMS such as the Balanced Scorecard (Kaplan/Norton 1996; 2001; 2004) and several other performance measurement frameworks (Keegan et al. 1989; Fitzgerald et al. 1991; Lynch/Cross 1991; Atkinson et al. 1997; Neely et al. 2001) are typically characterized by four determinants: multidimensionality, strategic focus, cascading, and an alignment with the incentive system. These determinants of PMS have been highlighted in both the professional and research literature. While multidimensionality - often established through a combination of financial and non-financial performance measures - and strategic focus characterize the content of contemporary PMS, cascading and alignment with compensation reflect their implementation perspective. Companies adopting such systems would improve their corporate profitability (Kaplan/Norton 2001; 2004; Simons 2000).

\section{Multidimensionality}

Contemporary PMS encompass multiple financial and non-financial perspectives, objectives, and performance measures (Garrison 1990; Eccles 1991; Fisher 1992; Kaplan/Norton 1996; 2004; Merchant/Bruns 1986). In the past, as companies invested in programs and initiatives to build their capabilities, managers relied solely on financial accounting reports. Today, financial information must be expanded to incorporate the valuation of the company's intangible and intellectual assets, such as committed and entrepreneurial employees, innovative internal processes, and loyal customers (Simons 2000). Extensive evidence indicates that the use of financial (accounting) performance measures in complex, dynamic, and uncertain environments results in dysfunctional managerial attitudes and behaviours, and low performance, which suggests that they should be complemented by qualitative or subjective performance measurement (Hartmann 2005). With financial performance measures, managers will primarily monitor results or past performance, while non-financial indicators provide leading information of future performance and enable managers to monitor the strategic drivers of success. From the perspective of economic theory: importance will be placed on additional, non-financial measures as long as such measures provide information beyond that contained in financial measures (Feltham/Xie 1994). While some 
specific non-financial performance measures, such as customer satisfaction and TQM, are positively associated with performance (e.g. Abernethy/Lillis 1995; Ittner/Larcker 1995; 1997; 1998; Chenhall 1997; Kaynak 2003; Said et al. 2003; Liang/Hou 2006), the prevailing argument is that managers need measurement diversity (i.e. multidimensionality of their PMS) to enhance decision-making (Davis/Albright 2004; Gersbach 1998; Ittner et al. 2003a; Kaplan/Norton 1996). Empirical evidence about the positive association between balanced performance measurement and increased financial performance is, however, still inconclusive: the results of studies are mixed and partial (i.e. Abernethy/Lillis 1995; Ittner/Larcker 1995, 1997; Chenhall 1997; Perera et al. 1997; Said et al. 2003; Ittner et al. 2003a), indicating that there are other determinants of effective PMS.

\section{Strategic alignment}

Companies with multidimensional PMS will place more importance on those performance measures that provide information directly relevant to their respective strategies and strategic success factors (Kaplan/Norton 1996; 2004). According to Simons (2000), an ideal PMS should consist of a linked series of multiple goals and measures that are both consistent and mutually reinforcing. This can be viewed as the instrumentation for a single strategy. Contemporary performance measurement is thus characterized by assigning equal importance to the purposes and objectives of an organization (outcomes) as well as the processes and other drivers of success such as R\&D investments, HRM policy, employee commitment, IT literacy etc. (Lynch/Cross 1991; Kaplan/Norton 1996; Atkinson et al. 1997). Measures must reflect the strategies and capabilities of the organization and not just the financial results. The main function of performance measurement in a strategic context, as claimed by Letza (1996), is to provide the means of control to achieve the objectives required and to fulfil a company's mission/strategy statement (see also Fawcett et al. 1997). A number of studies attempted to examine how the diversified performance measures are linked to organizational strategy. Perera et al. (1997), for example, argue that a customer-focused strategy is comprised of dimensions that are not well captured in traditional financial accounting information, and therefore, non-financial information would be more relevant. Higher linkages are reported by BSC users between performance measures and critical success factors, than by non-BSC users (Frigo/Krumwiede 1999). Rejc Buhovac and Slapničar (2007) find that focused performance measurement that is also well aligned with the business strategy (and further supported by tight control mechanisms) improves a firm's profitability. 


\section{Cascading}

As noted earlier, multidimensionality and strategic focus represent the two content-related determinants of contemporary PMS, while cascading is the process factor that is needed to achieve high PMS effectiveness. A sound PMS will cascade down the organization. It will be integrated with the overall business strategy and so ensure that all stakeholders are working together in the same direction (Latest Trends in Corporate Performance Measurement, 2002). A number of accounting and strategic management studies indicate that in many companies managers at lower hierarchical levels rely exclusively on financial control systems that place too much emphasis on budgets and short-term profits, potentially hiding strategic problems from management and causing business managers to adopt a short-term perspective in their decisions (Ittner/Larcker 1997). Strategic control systems, on the other hand, include the development of action plans and targets for achieving the chosen strategic objectives, but also the assignment of responsibilities and alignment of reward systems with strategic objectives to ensure that managers' actions are consistent with the strategic goals and to avoid over-emphasis on short-term financial results (Govindarajan/Gupta 1985; Goold/Quinn 1990; Govindarajan/Shank 1995; Chenhall 2005). As the purpose of performance measures includes aligning employees with the business strategy and mission (Kaplan/Norton 1996; Simons 2000), the company's overall PMS would ideally be broken down into sets of local measurements for lower-level units to cascade the company's strategic objectives into more manageable subsets.

\section{Alignment with the incentive system}

The need for aligned performance measurement and incentive systems has been intensely accentuated in the literature (Merchant 1989; Bruns 1992; Kohn 1993; Ittner/Larcker 1995; Symons/Jacobs 1995; Ittner et al. 1997; Datar et al. 2001; Ittner et al. 2003a). Even multidimensional, strategic, and cascaded PMS may fail in coordinating employee efforts and their decision-making if not linked to the incentive system (Simons 2000; Kaplan/Norton 2001). Through better alignment of performance measurement and incentive systems, corporate performance is improved because the goals of the managers and their subordinates are brought into line with corporate strategy and goals and this in turn should result in enhanced performance. Holmstrom and Milgrom's (1991) analytical model shows that management decisions are affected by performance measures included in their performance evaluation and compensation schemes. The 'linkage' between PMS and compensation focuses employee attention on the measures that are the most critical for the strategy, and it provides extrinsic motivation by rewarding employees when they succeed in reaching the company objectives (Kaplan/Norton 2001). In an earlier study, Govindarajan and Gupta (1985) examined the association between strategy and remuneration and concluded that perceived organizational performance was higher when reward 
systems were matched with organizational strategies. Symons and Jacobs (1995) indicate that in companies pursuing quality strategy, TQM-based reward systems are associated with higher performance. A well-developed incentive scheme may represent a crucial link between PMS and organizational performance by guiding employee behaviour in the direction of strategy implementation and thus contributing to the goal congruence.

\section{A synthesis of contemporary performance measurement systems literature in Central and Eastern Europe}

The four determinants of contemporary PMS provide a solid basis for evaluating the empirical PMS literature in CEE. Accordingly, we synthesize the literature by evaluating research contribution related to the multidimensionality, strategic content, cascading, and the alignment of performance measurement and incentive systems. Such a synthesis of the literature should facilitate the understanding of the empirical PMS literature in CEE and provide a structured means for identifying future research needs and opportunities. Summaries of relevant research findings are provided at the end of each section. Each subsection is accompanied by a table classifying CEE studies by author, research method, companies (by country and numbers where available), focus of the study, and principal findings.

\section{Multidimensionality}

The most numerous studies of contemporary performance measurement systems in CEE countries are those focusing on their multidimensionality. One of the most common variables in this line of investigation is the use of financial and non-financial performance measures for decision-making, diagnostic, and interactive purposes (Vrdoljak Raguž/Jelenc 2010; Peljhan et al. 2009; Horváth et al. 2008; Pärl 2006; Vitezić/Knez-Riedl 2005; Rejc/Slapničar 2004; Vitezić 2004; Rejc 2003). Most studies of SMEs find that there is a strong focus on financial performance measures (see for example, Peljhan et al. 2009; Pärl 2006). Studies of large companies, on the other hand, reveal a relatively high level of knowledge and use of multidimensional PMS (Marc et al. 2010a; Peljhan et al. 2009; Horváth et al. 2008; Rejc/Slapničar 2004; Rejc 2003; Čadež 2002). To the contrary, Vitezić/Knez-Riedl (2005), Vitezić (2004), Vrdoljak Raguž and Jelenc (2010) investigating Croatian companies, and Llaci et al. (2002) investigating Albanian companies, find that regardless of the size of the company, PMS are dominated by financial and accounting information. Renko and Pecotich (2001), investigating three case studies, find that all case companies are familiar with the Balanced Scorecard concept but they did not implement it in its formal configuration.

A couple of studies examine trends in performance measurement and management control through longitudinal studies. For example, Zoltay Paprika et al. (2008) reported that through an 8-year period, companies managed to 
narrow the "gap" between the perceived importance of various non-financial performance elements and the actual use of related measures of performance. Bodnár et al. (2007) found that the use of comprehensive and complex performance measurement systems was hindered by system implementation obstacles.

A couple of multidimensionality studies investigate the role of various contingent factors of PMS. Rejc (2004) found that PMS multidimensionality was contingent upon the power of unions, technology, and corporate strategies. Haldma and Lääts (2002) confirmed that changes in management accounting and performance measurement systems practices were associated with shifts in the business and accounting environment, with legal accounting environment, shortage of qualified accountants, technology, and organizational aspects. Vámosi (2000), using a case study, found the environment an important contingent factor of the development of accounting and reporting practice. Marc et al. (2010b) explored how contextual factors (company size, industry, or market position), business objectives, and knowledge about contemporary management tools influence the decision to implement the Balanced Scorecard or similar integrated PMS. Company size, industry, and management knowledge have been confirmed as contingencies. In a descriptive study of 145 Estonian companies, Zernand-Vilson and Terk (2009) find that size, ownership, and export orientation bear impact on the use of the Balanced Scorecard.

Other studies include investigation of the role of accounting and financial departments in designing PMS (Lascu et al. 2006; Szychta 2002). In a Polish survey study, Szychta (2002) finds that the primary aim of accounting is to provide information for the preparation of financial statements. In another Polish study, Lascu et al. (2006) confirm that finance, accounting, and production, continue to retain their dominant status from the days of socialist planning when production and costs, rather than consumers and their needs, were being focused on.

Yet another set of studies examines the specifics of management control systems of foreign subsidiaries. In an earlier study, Hočevar et al. (2001) reported on the importance of financial indicators (such as paid realization and contribution margin). A later study by Zaman (2004) found that the four BSC perspectives are adequately represented within PMS. Somewhat disregarded are the measures of social responsibility, such as »environmental compliance« and »relationship with the host country government $\ll$.

The empirical literature related to multidimensionality of PMS in CEE countries also extends beyond these topics to examine the impact of multidimensional (balanced) PMS on financial performance. Rejc Buhovac and Slapničar (2007) found that focused (rather than balanced) performance measurement, but well aligned with the business strategy and further supported by tight control mechanisms, may actually improve a firm's profitability. 


\section{Table 1: Multidimensionality Studies}

\begin{tabular}{|c|c|c|c|c|c|c|}
\hline & 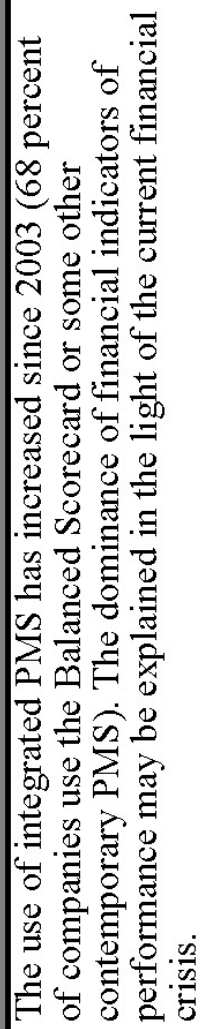 & 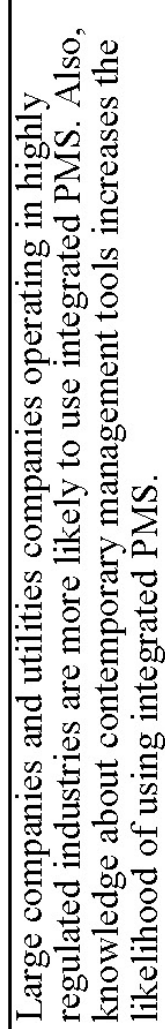 & 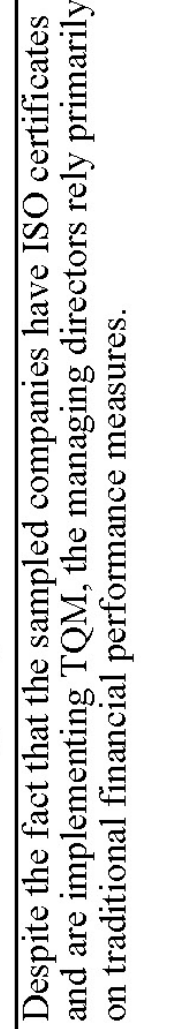 & 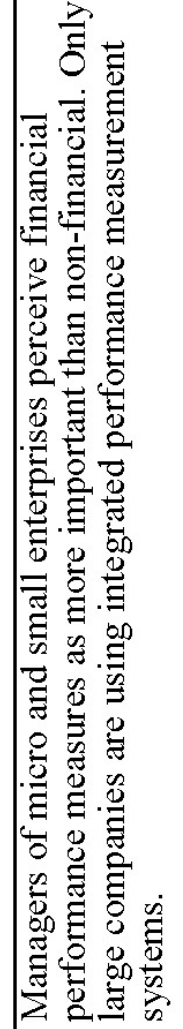 & 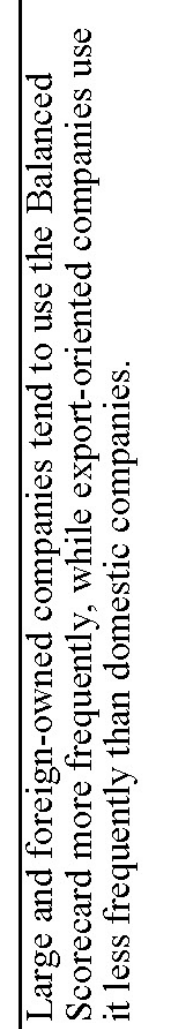 & 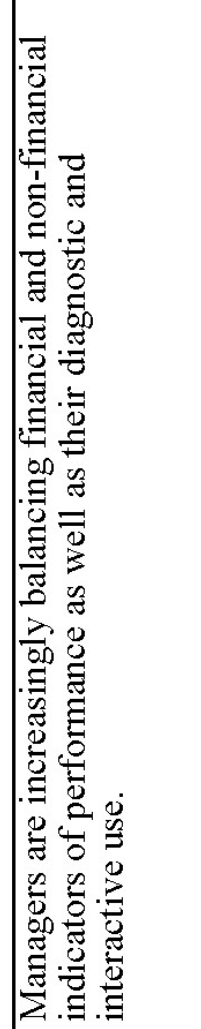 \\
\hline & 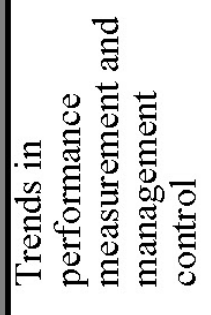 & 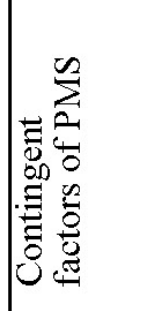 & 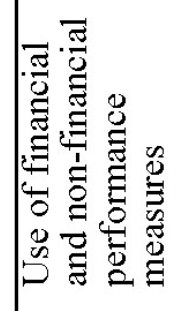 & 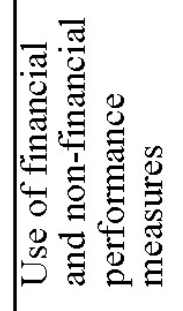 & 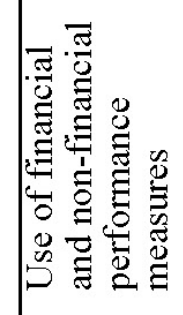 & 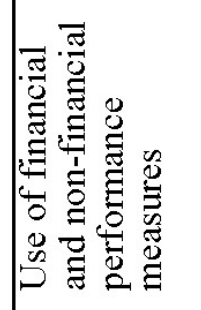 \\
\hline 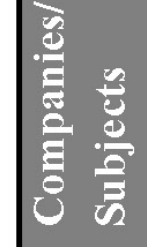 & 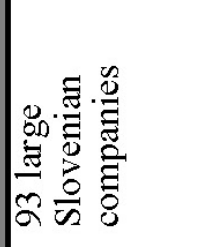 & 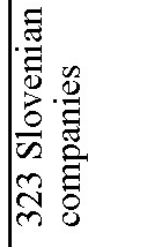 & 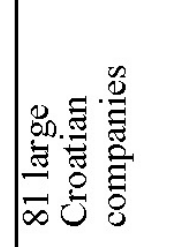 & 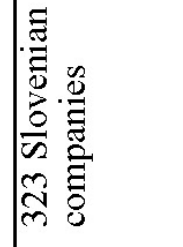 & 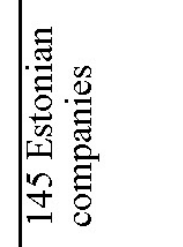 & 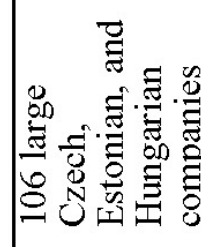 \\
\hline 응 & 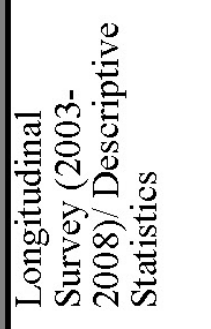 & 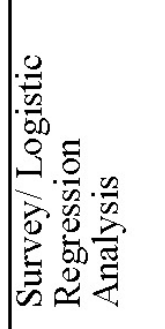 & 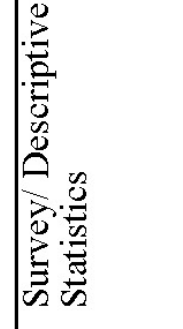 & 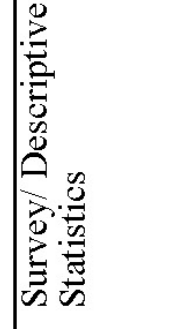 & 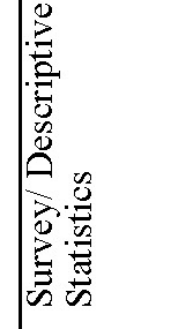 & 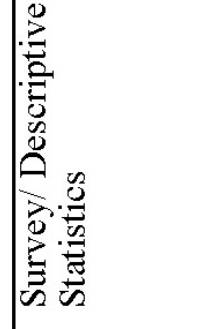 \\
\hline E & 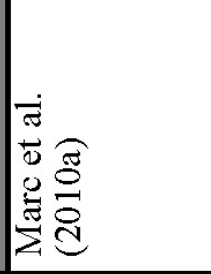 & 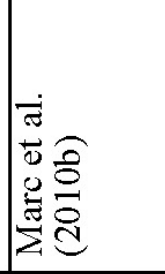 & 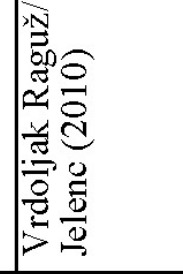 & 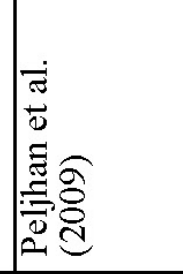 & 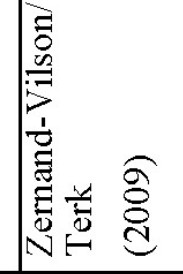 & 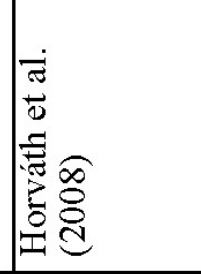 \\
\hline
\end{tabular}




\begin{tabular}{|c|c|c|c|c|}
\hline 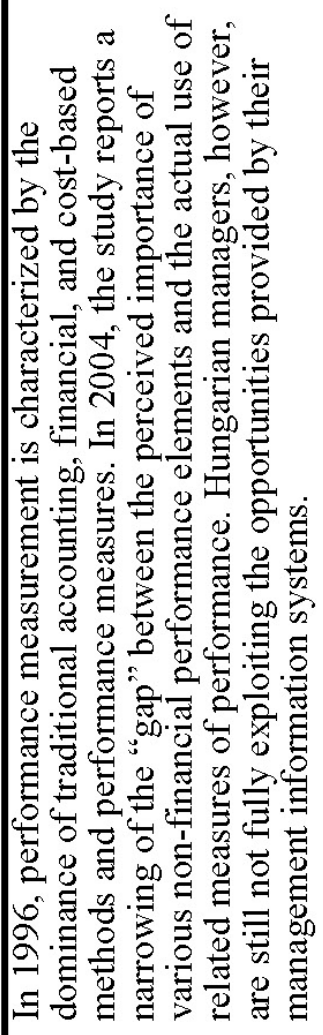 & 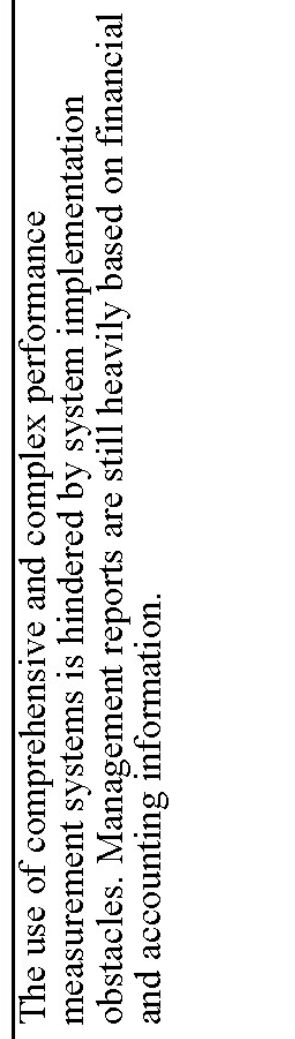 & 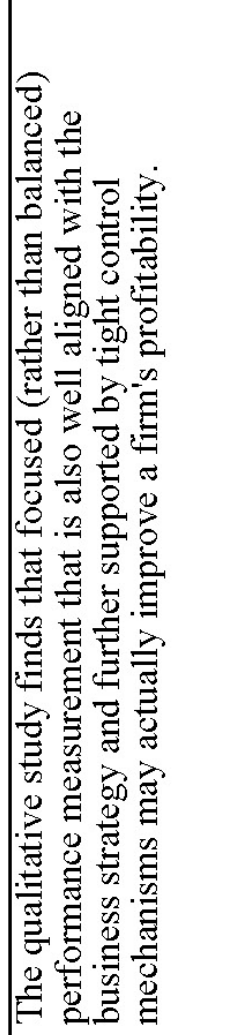 & 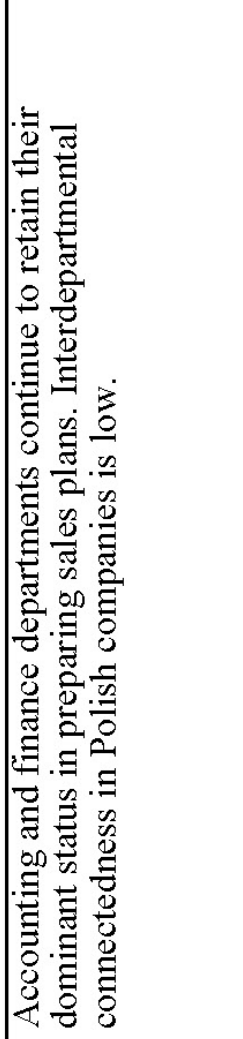 & 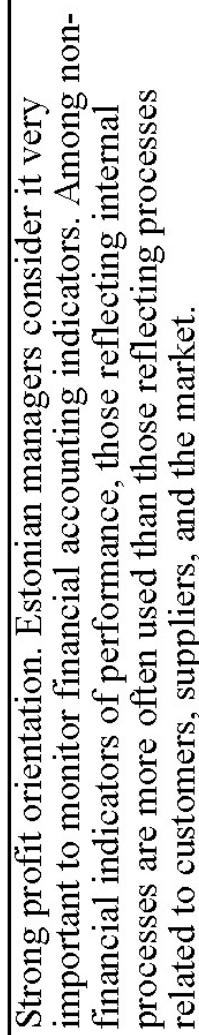 \\
\hline 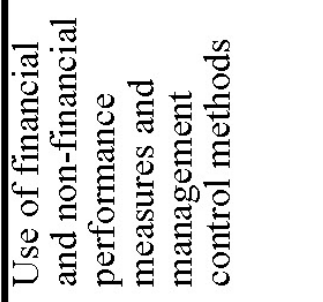 & 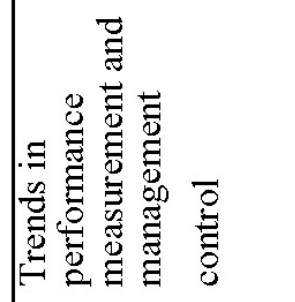 & 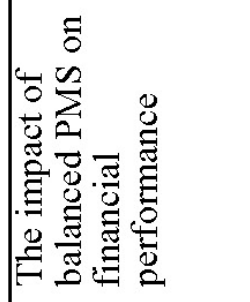 & 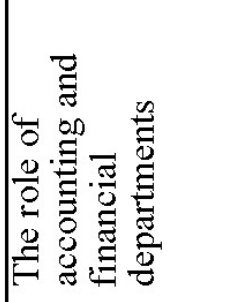 & 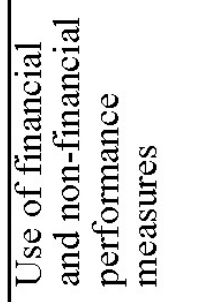 \\
\hline 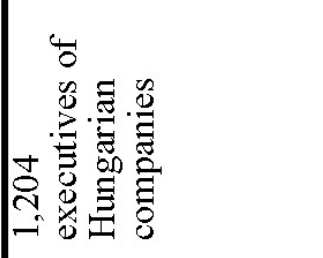 & 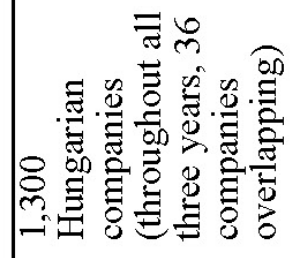 & 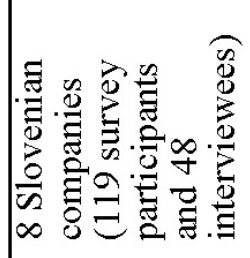 & 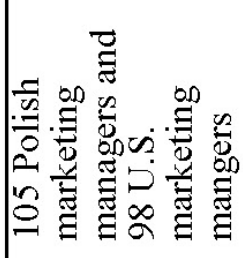 & 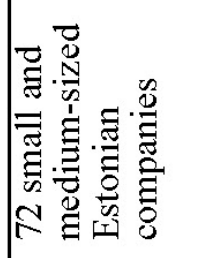 \\
\hline 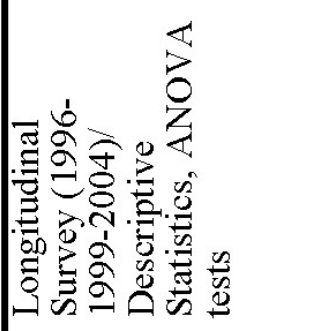 & 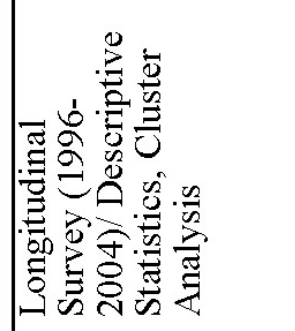 & 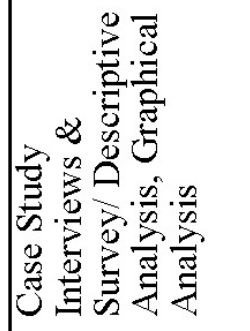 & 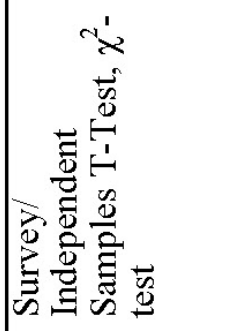 & 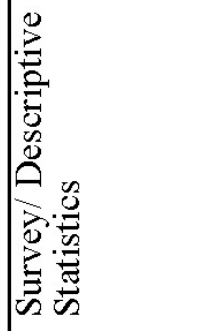 \\
\hline 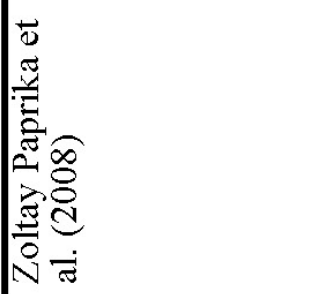 & 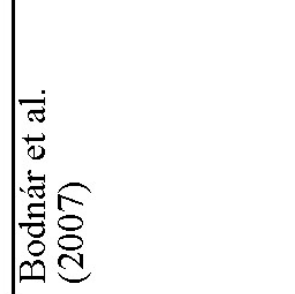 & 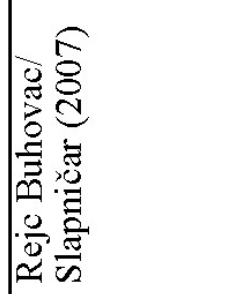 & 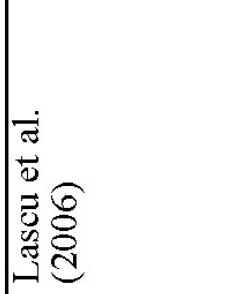 & 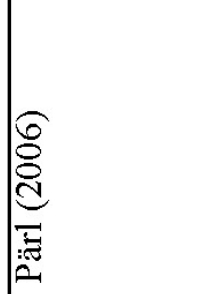 \\
\hline
\end{tabular}




\begin{tabular}{|c|c|c|c|c|c|c|}
\hline 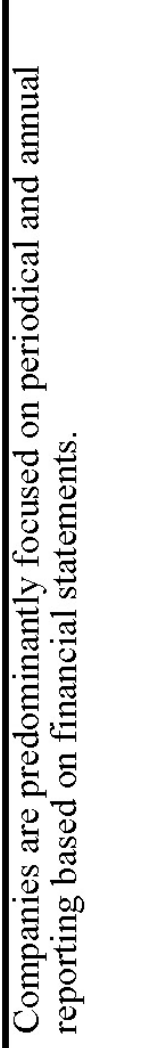 & 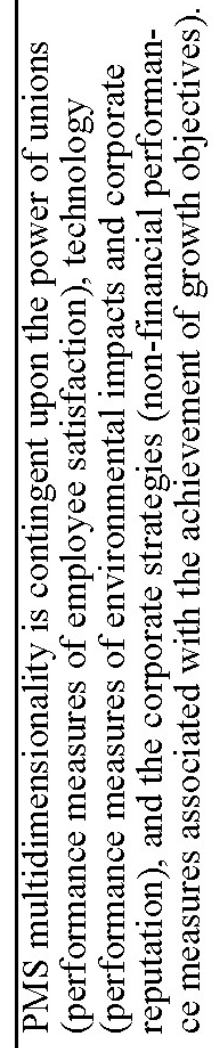 & 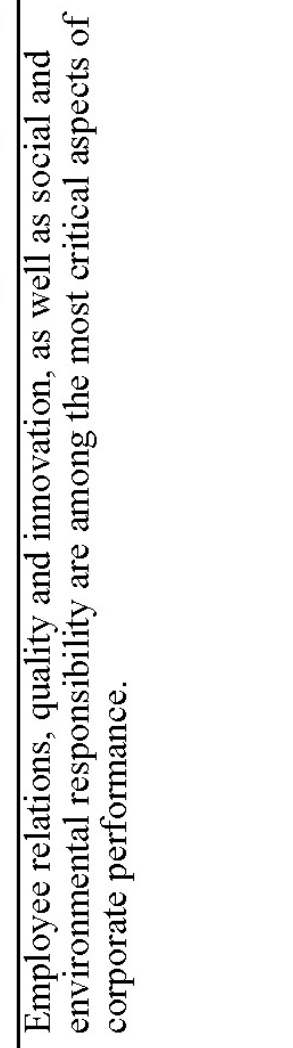 & 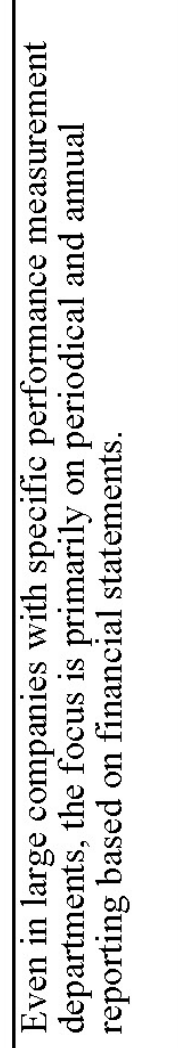 & 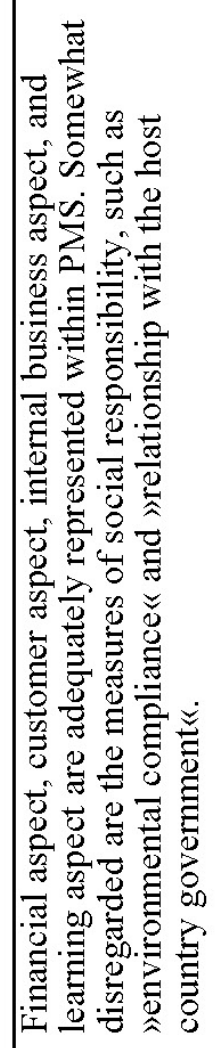 & 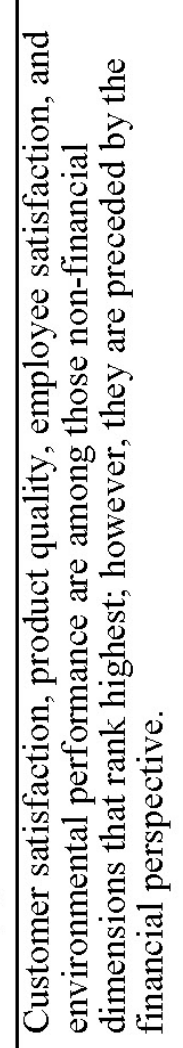 & 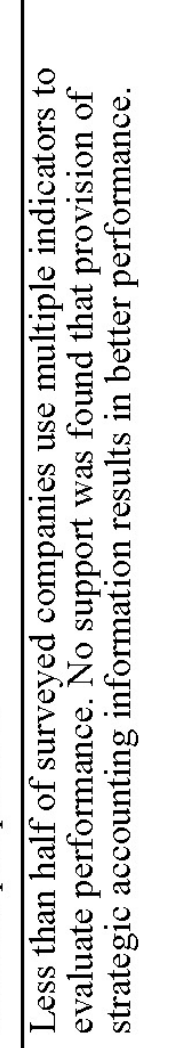 \\
\hline 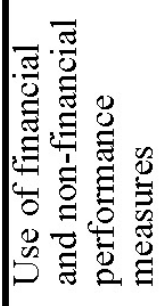 & 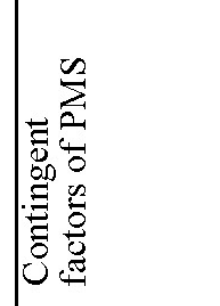 & 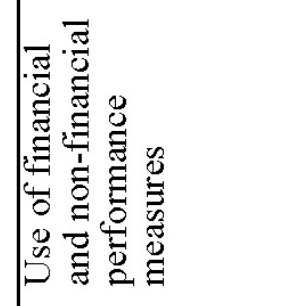 & 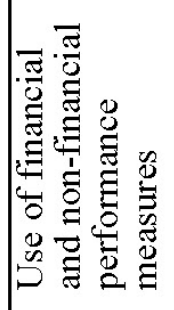 & 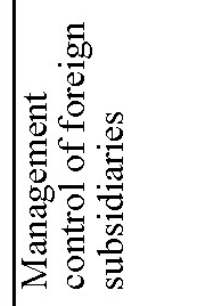 & 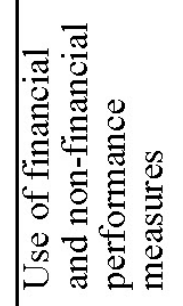 & 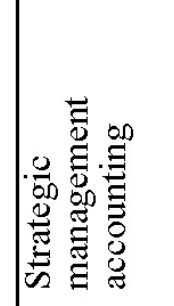 \\
\hline 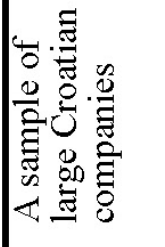 & 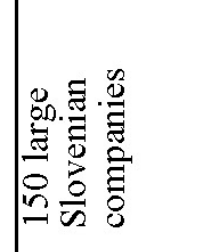 & 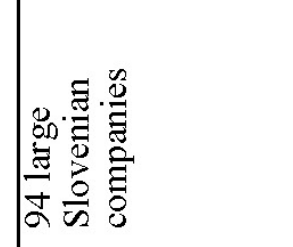 & 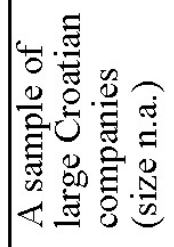 & 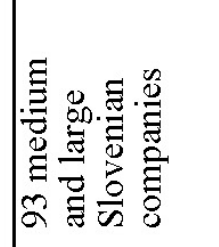 & 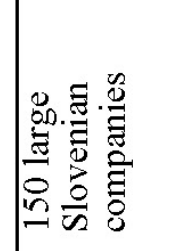 & 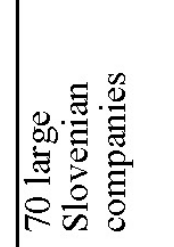 \\
\hline 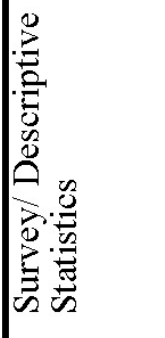 & 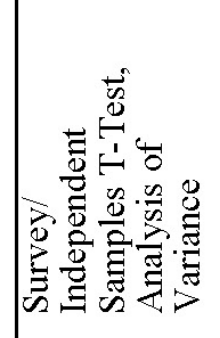 & 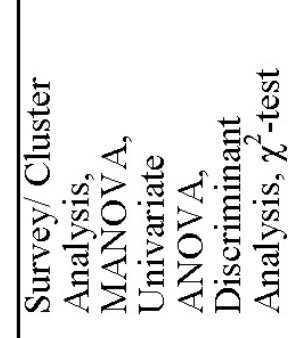 & 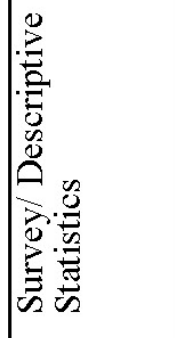 & 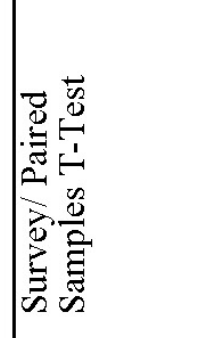 & 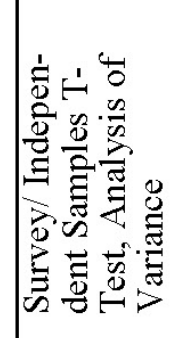 & 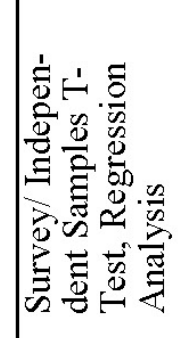 \\
\hline 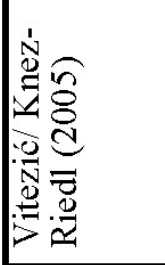 & 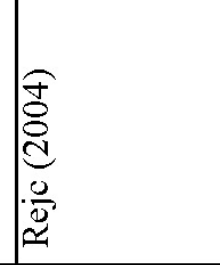 & 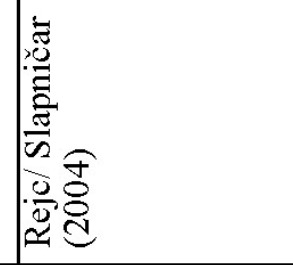 & 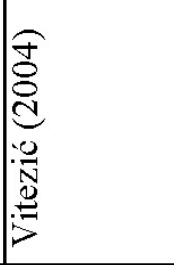 & 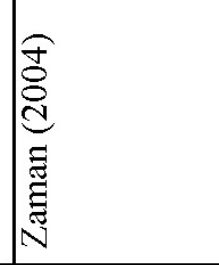 & 㫋 & 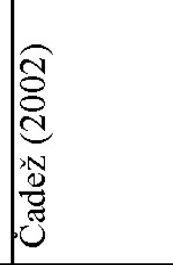 \\
\hline
\end{tabular}




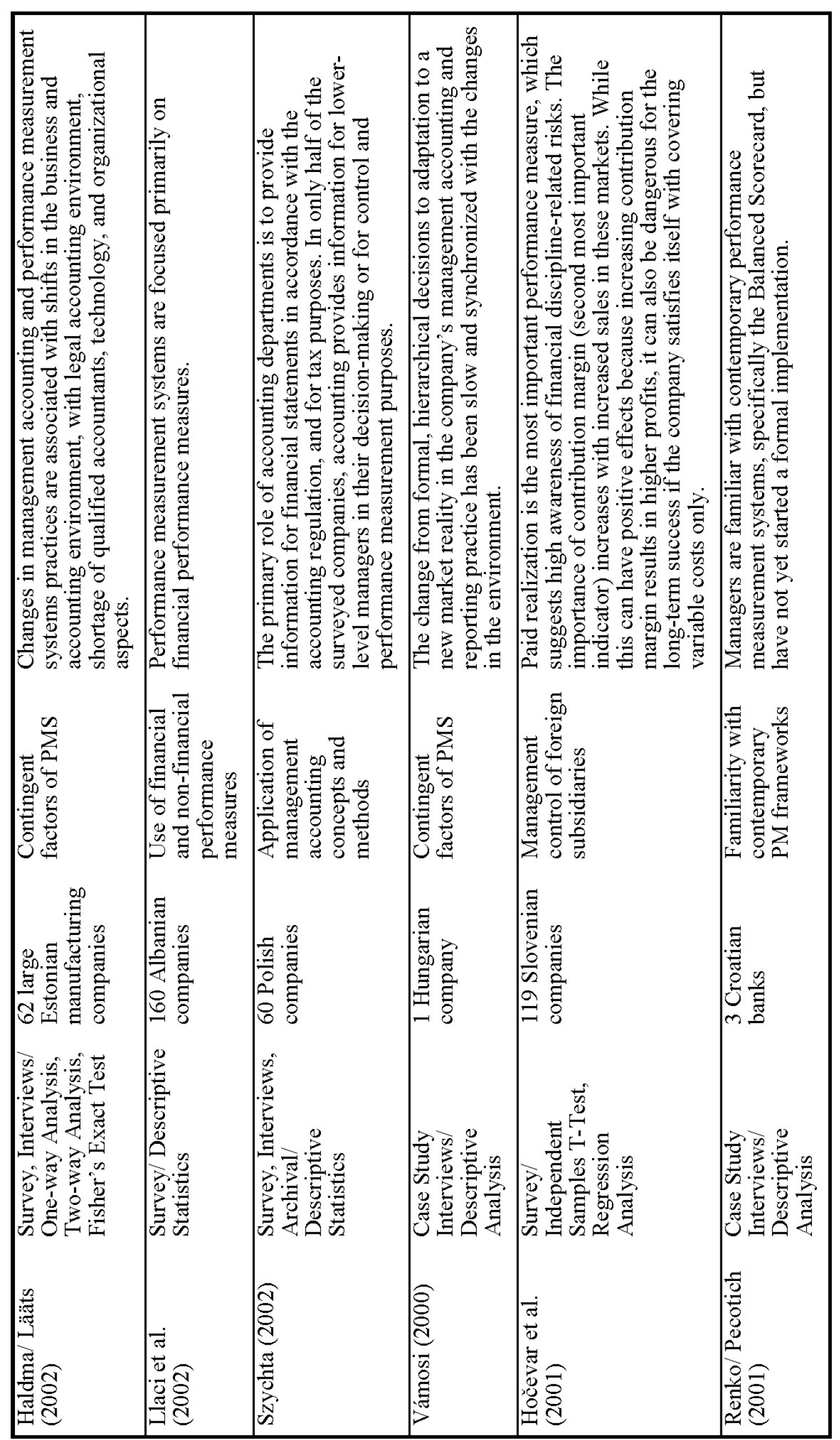


A reflective review of the findings of CEE multidimensionality studies (see Table 1) reveals the following common denominators. First, analysis of studies by year reveals apparent trends from predominant reliance on financial measures toward the usage of more balanced PMS (Hočevar et al. 2001; Llaci et al. 2002; Čadež 2002; Haldma/Lääts 2002; Szychta 2002; Rejc 2003; Horváth et al. 2008; Zoltay Paprika et al. 2008; Marc et al. 2010a).

Second, more recent studies reveal that large companies are more likely to use integrated PMS (Marc et al. 2010b; Peljhan et al. 2009) than small companies (Pärl 2006). Both findings are related to the lack of the management accounting knowledge at the management level, reported by Čadež (2002) and Pärl (2006). Čadež (2002) reported that although management information system provided relevant information for decision-making, managers exploited the information insufficiently because of the lack of accounting knowledge to interpret the provided information. Pärl (2006) reports that managers consider it extremely important to monitor financial accounting information. They regard financial indicators as clear and easy to understand, which reflects the need for management accounting related training to enable managers to recognize alternative (non-financial) indicators. The trend towards more integrated PMS suggests that knowledge problems are being exceeded.

Third, some conclusions regarding the multidimensionality of PMS cannot be generalized across all CEE countries. For example, employee power is a contingency factor, influencing development of performance measurement systems in those transitional countries which have experienced the selfmanagement regime. In countries with strong trade unions, performance measurement systems are more focused on employee interests and performance measures such as employee satisfaction are more emphasized than in other countries (Rejc 2003; 2004; Rejc/Slapničar 2004).

\section{Strategic alignment}

A number of studies highlight the strategic alignment of PMS. Some studies investigate the level and nature of strategic performance measurement (Bratnicki et al. 2009; Peljhan et al. 2009; Král et al. 2007; Alas/Zernand 2002; Slávik 2001). Alas and Zernand (2002) found that SMEs rarely implemented integrated, strategic PMS. Král et al. (2007) found that the intensity of use of strategic management tools in Czech companies was significantly lower compared to the tactical and operational management tools. Slávik (2001) reports similar findings in an earlier study on Slovak companies.

Another group of researchers specifically investigated the impact of strategic goals on the design of PMS. Wagner et al. (2007) reported inconclusive findings. PMS typically emphasized financial and customer perspectives, while other perspectives were not fully integrated in PMS. Pučko and Čater (2008), on the other hand, investigated the impact of PMS on strategy effectiveness. The 
Balanced Scorecard was found to be less relevant for effective strategy implementation. Less than 20 percent of surveyed companies used the BSC for strategy implementation purposes.

In a single study, researchers examined the management accountant participation in strategic performance measurement. Aver and Čadež (2009) reported that Slovenian management accountants were relatively strongly involved in the strategic management process, although the level of participation varied intensely across industries.

A couple of empirical studies moved beyond investigating whether there is a strategic alignment to determine the impact of strategic PMS (also called strategic management accounting) on company performance. In an earlier study, Čadež (2002) found that the provision of strategic accounting information did not result in better performance because management did not incorporate this information in the decision-making process. According to the survey, insufficient exploitation of provided accounting information for decisionmaking was related to the lack of accounting knowledge to interpret the provided information. Later, Čadež and Guilding (2008) confirmed the positive effect of strategic choices, market orientation, and company size on two distinct dimensions of strategic management accounting (accountant participation in strategic decision-making process and strategic management's usage of accounting) and, in turn, the mediating effect of strategic management accounting on company performance. Using a qualitative study, Rejc Buhovac and Slapničar (2007) found that despite the relatively consistent alignment of performance indicators with the corporate and business strategy, poor cascading and a lack of alignment to incentive systems prevented companies from increasing their financial performance. 
Table 2: Strategic Alignment Studies

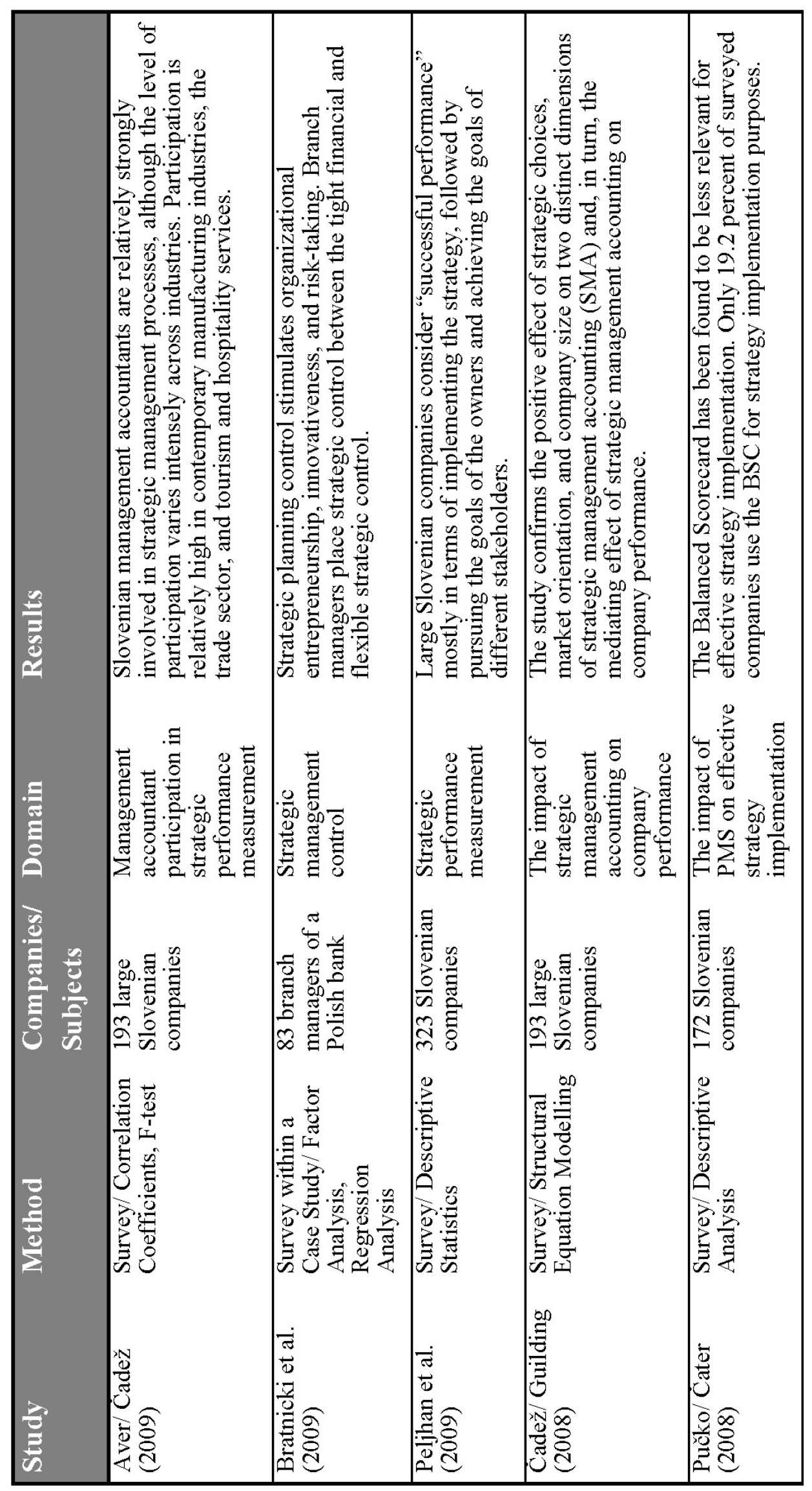




\begin{tabular}{|c|c|c|c|c|c|}
\hline 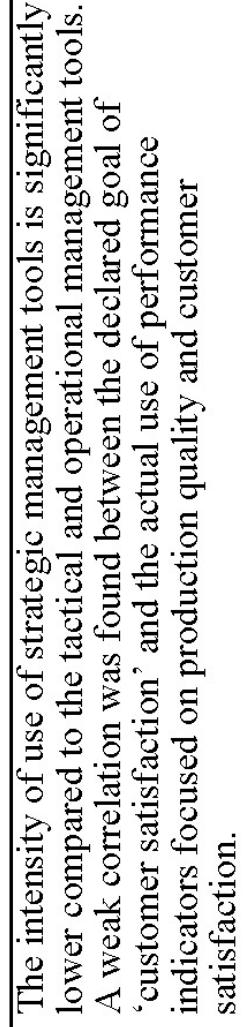 & 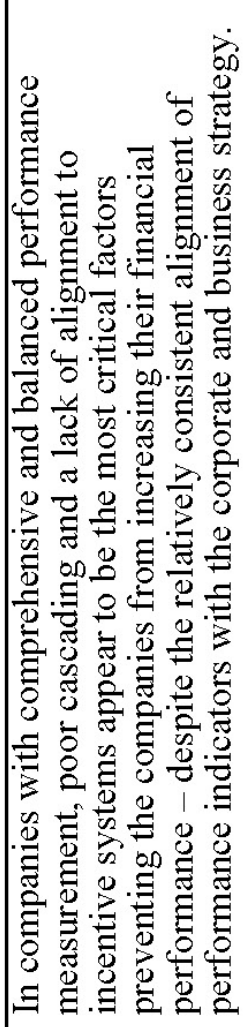 & 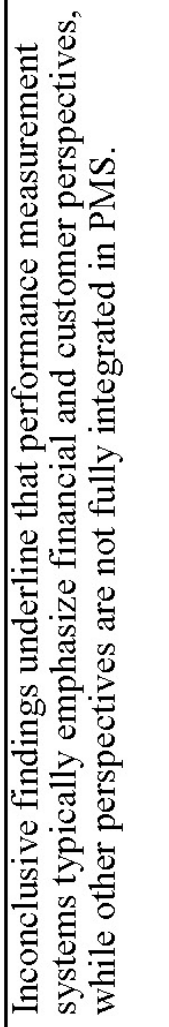 & 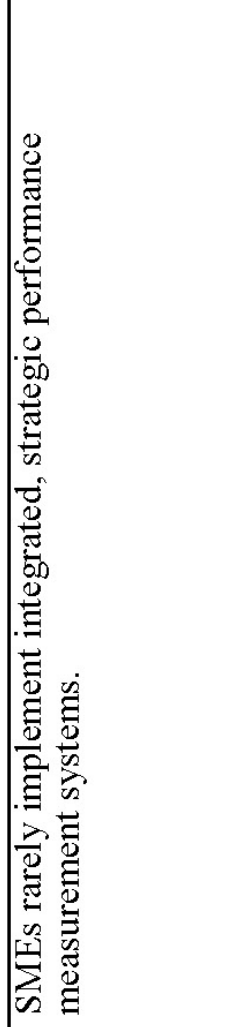 & 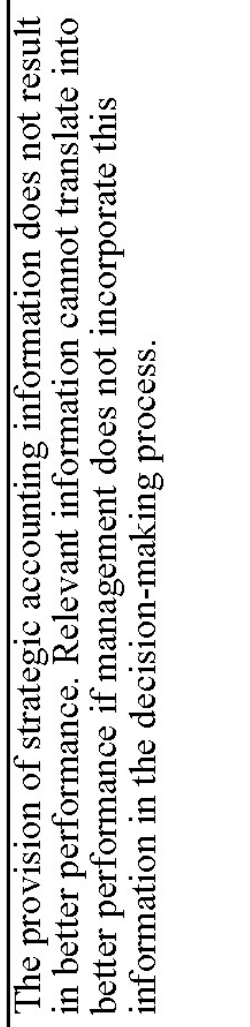 & 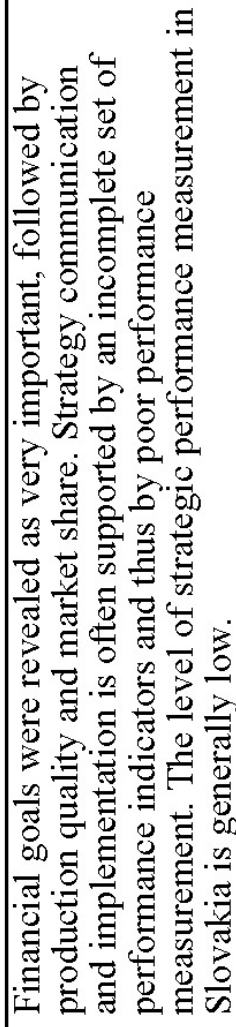 \\
\hline 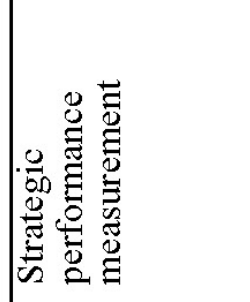 & 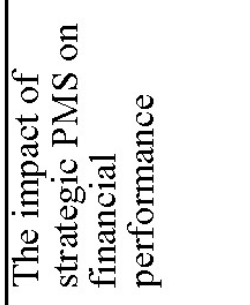 & 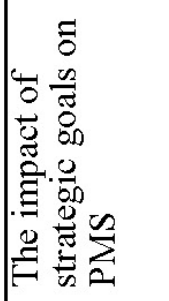 & 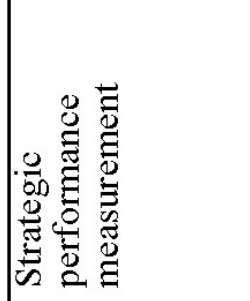 & 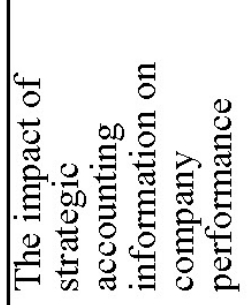 & 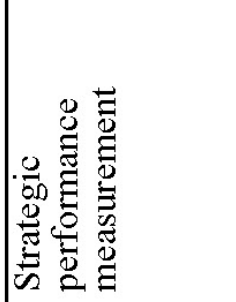 \\
\hline 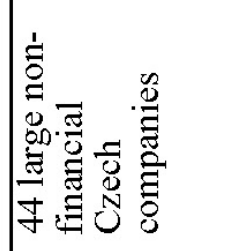 & 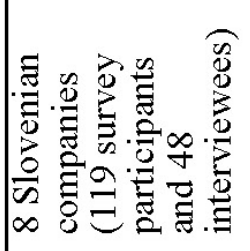 & 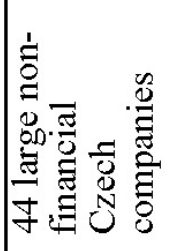 & 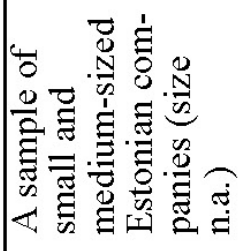 & 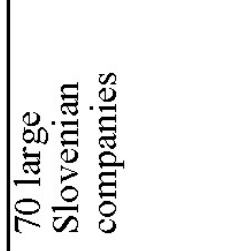 & 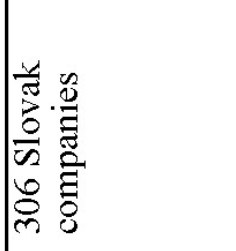 \\
\hline 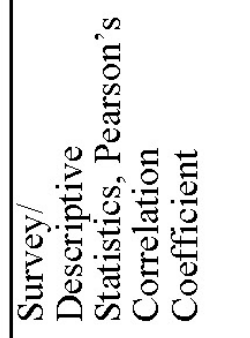 & 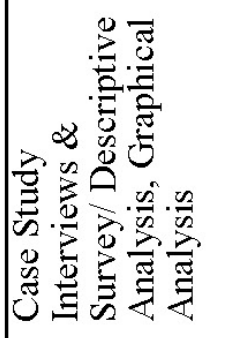 & 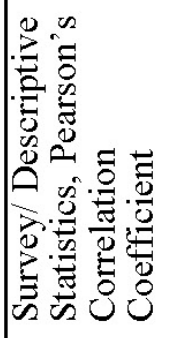 & 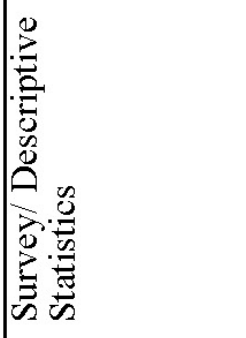 & 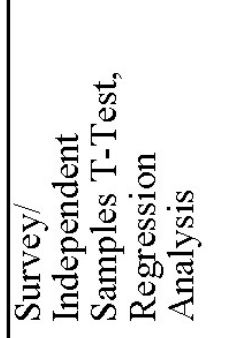 & 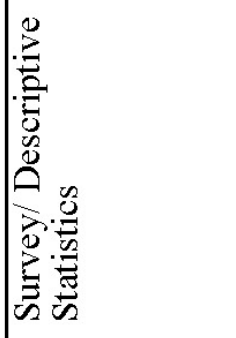 \\
\hline 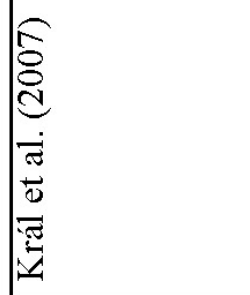 & 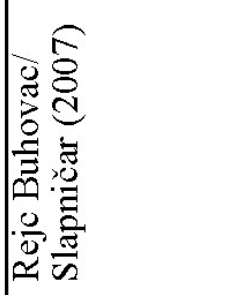 & 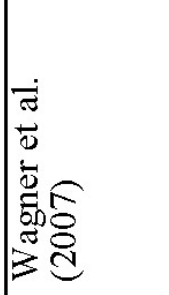 & 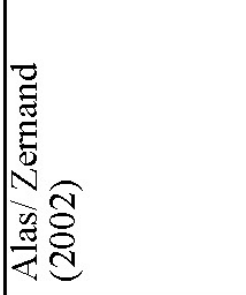 & 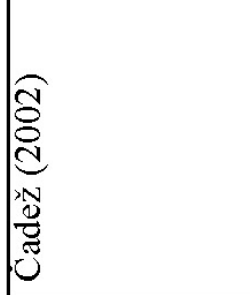 & 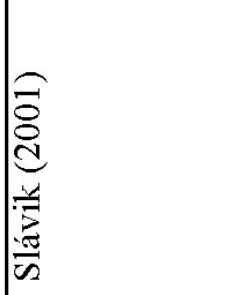 \\
\hline
\end{tabular}


From the analysis of findings, resulting from the existing strategic alignment studies (Table 2) in the CEE, two principal conclusions can be drawn. First, strategy implementation purposes are not fully integrated in corporate PMS (Pučko/Čater 2008; Král et al. 2007; Wagner et al. 2007; Alas/Zernand 2002; Slávik 2001). Second, recent studies report some positive effects of strategically aligned PMS on organizational entrepreneurship, innovativeness (Bratnicki et al. 2009) and performance (Čadež/Guilding 2008). However, poor cascading and a lack of alignment to incentive systems appear to be the most critical factors preventing companies from increasing their financial performance in companies with relatively consistent alignment of performance indicators with the corporate and business strategy (Rejc Buhovac/Slapničar 2007).

\section{Cascading}

Empirical research involving PMS cascading in CEE countries is rather rare. Four studies were found which investigate this critical issue (see Table 3).

An early study (Bodnár/Dobák 1998) surveyed Hungarian companies with regard to the practice of Balanced Scorecard implementation. Researchers found that the elaboration of the BSC was typically limited to a single organizational unit. A survey by Pučko and Čater (2008) investigated normative attitudes of managers toward cascading. Managers of companies with the BSC suggested that the BSC could not be efficient unless it was applied in each business unit as well as at the corporate level.

A two-stage multiple case study (research findings were published in two consecutive papers, i.e. Epstein et al. 2004; Rejc Buhovac/Slapničar 2007) investigated the impact of PMS cascading on financial performance. In both studies, cascading was found as one of the two critical elements (alignment with incentive system being the second) in enhancing a firm's performance. More specifically, qualitative studies revealed that multidimensional and balanced performance measurement with poor cascading and a lack of alignment to compensation did not increase financial performance.

\section{Alignment with incentive systems}

A review of research of PMS alignment with incentive systems highlights several interesting findings. Two studies investigated the general alignment between PMS and incentive systems. Bodnár et al. (2009) found that poorly elaborated soft management systems (such as implicit motivation through top management commitment, open communication, supportive organizational atmosphere etc.) led to unsuccessful implementation and use of the BSC. Wagner et al. (2007) similarly reported that PMS were not supported by explicit motivation systems throughout the organizations. Rather, performance-based compensation was more frequent for executives than for non-executives. 


\section{Table 3: Cascading Studies}

\begin{tabular}{|c|c|c|c|c|}
\hline 尊 & 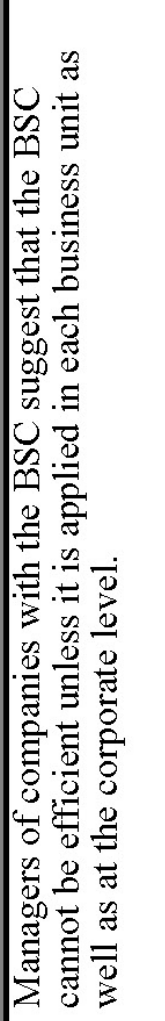 & 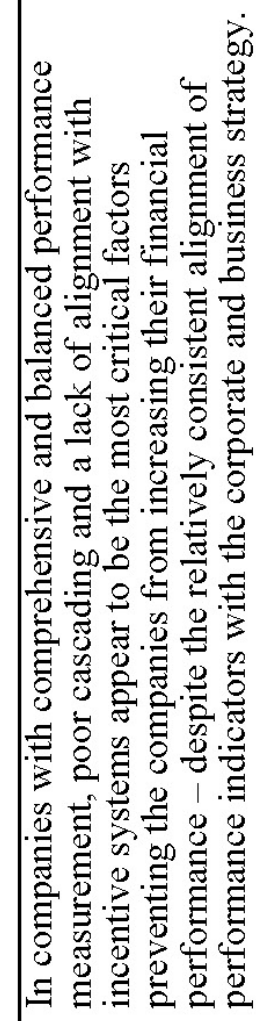 & 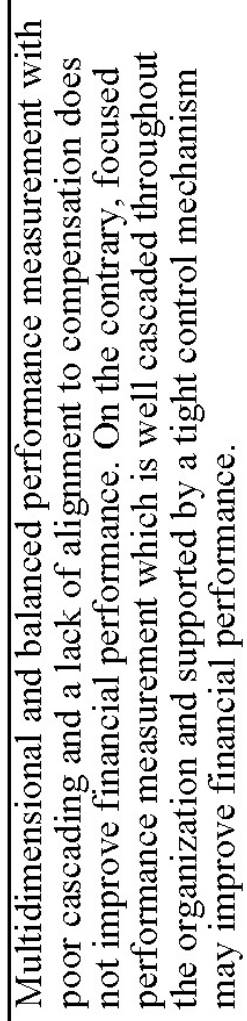 & 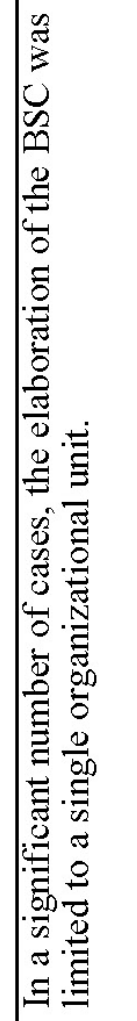 \\
\hline 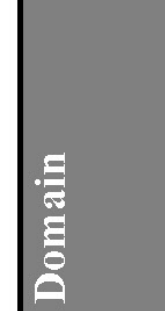 & 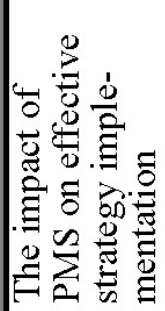 & 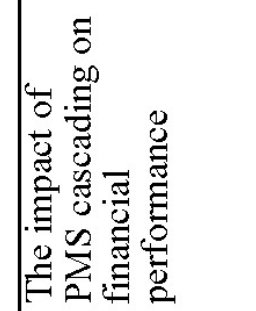 & 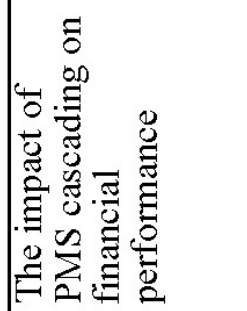 & 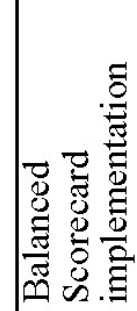 \\
\hline 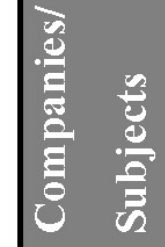 & 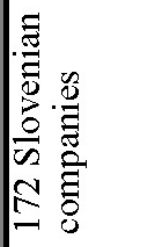 & 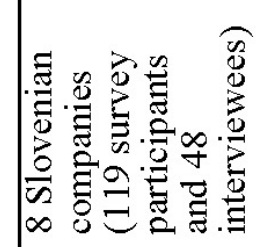 & 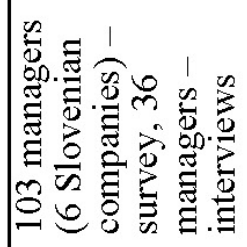 & 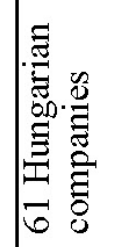 \\
\hline 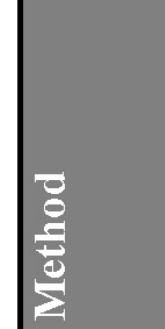 & 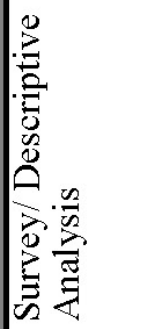 & 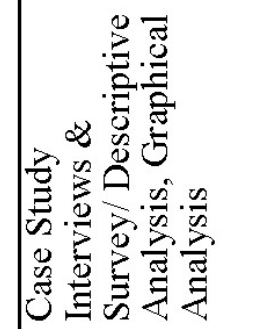 & 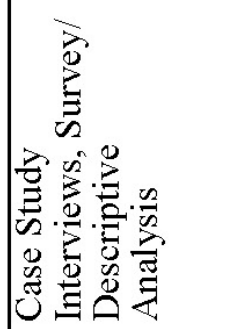 & 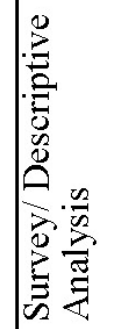 \\
\hline 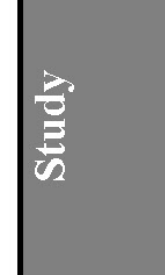 & 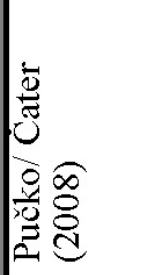 & 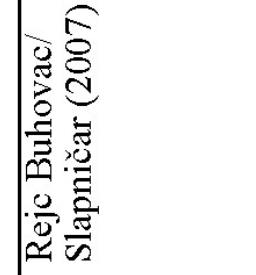 & 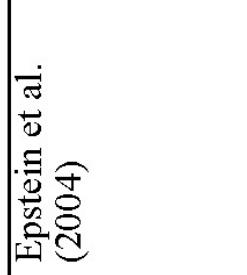 & 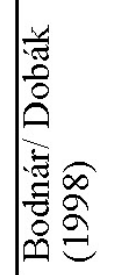 \\
\hline
\end{tabular}


Pučko and Čater (2008) investigated the managers' normative attitudes toward the alignment of PMS and incentive systems. Researchers expectedly found that managers of companies with the BSC suggested that the BSC could not be efficient unless it was supported by an appropriate reward system.

Regarding the impact of compensation schemes on the design and use of PMS, Rejc and Slapničar (2003) found no support for the hypothesis that the inclusion of traditional performance measures in managing directors' compensation contracts stimulates consideration of the same type of performance measures in internal performance measurement systems. A specific investigation of PMS and incentive systems in foreign subsidiaries by Hočevar et al. (2001) reported that the majority of companies used the same profit to evaluate the performance of both, subsidiaries and their management. Performance evaluation system which does not distinguish between controllable and uncontrollable factors, results in sub-optimal decisions related to investment and management motivation.

As already noted, two multiple case studies (Epstein et al. 2004; Rejc Buhovac/Slapničar 2007) investigated the impact of PMS alignment with incentive systems on financial performance. The first qualitative study found that companies with comprehensive and balanced PMS, but with a lack of alignment of these PMS to compensation, failed to improve their financial performance. The other qualitative study complemented these conclusions with the finding that in complex and dynamic business environments effective organizations may combine tight controls with more open, informal and flexible information and communication systems to stimulate and channel employee behaviour toward the achievement of overall organizational goals, rather than implement formal incentive systems aligned with PMS.

The findings drawn from the existing contributions of the research focusing on the PMS alignment with incentive systems (Table 4) support the notion that incentive systems in CEE companies are not well aligned with performance measurement systems (Bodnár et al. 2009; Wagner et al. 2007; Hočevar et al. 2001; Epstein et al. 2004), although managers recognize that PMS cannot be efficient unless they are supported by an aligned incentive system (Pučko/Čater 2008). 
Table 4: Alignment with the Incentive System Studies

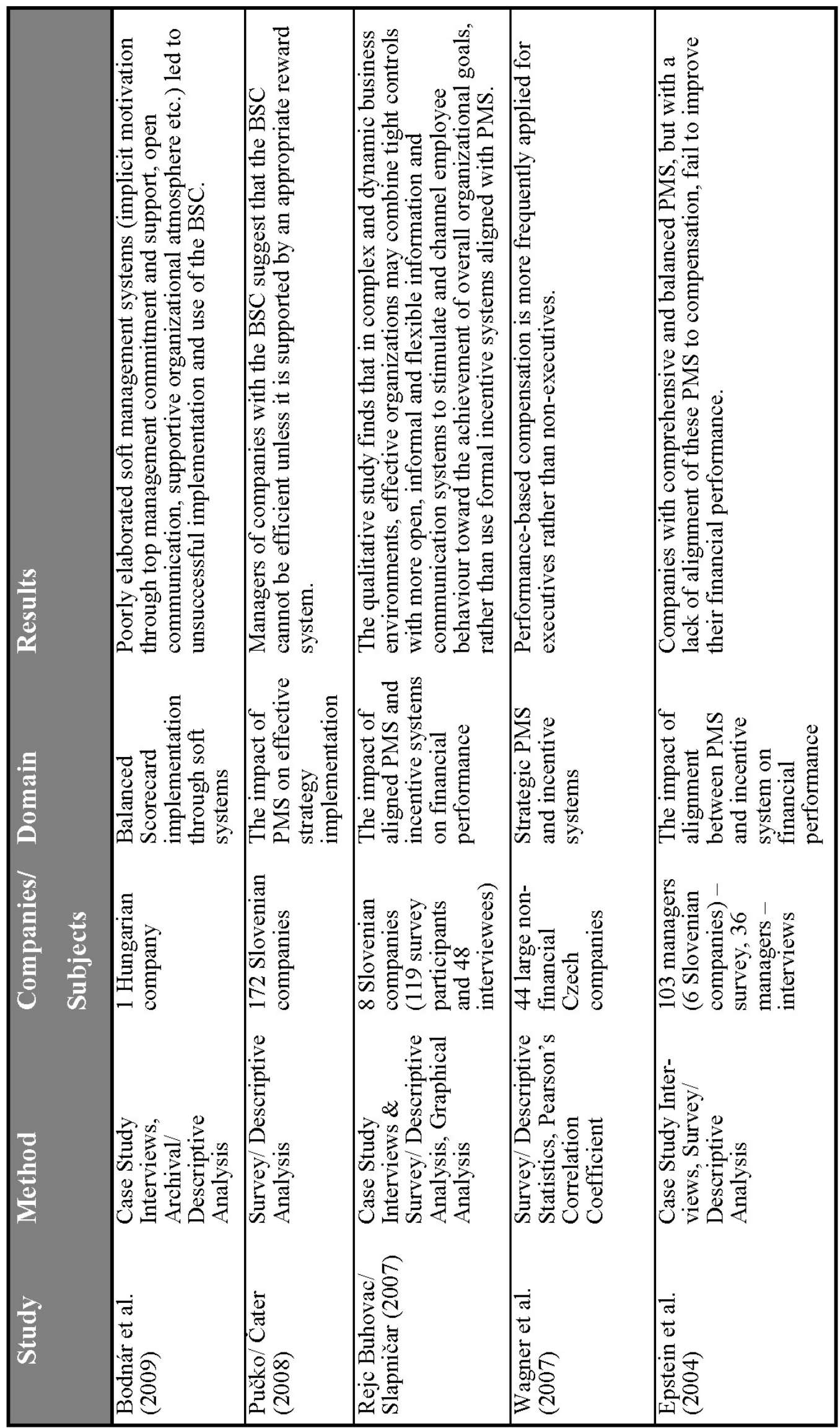




\begin{tabular}{|c|c|}
\hline 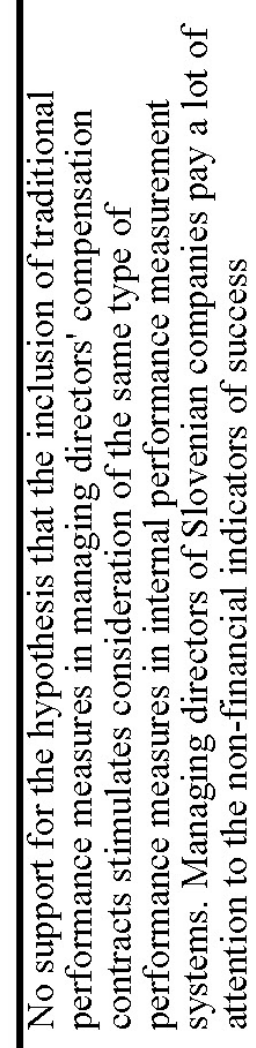 & 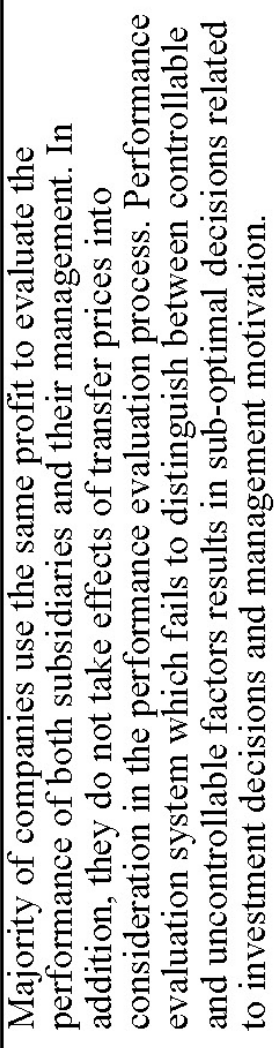 \\
\hline 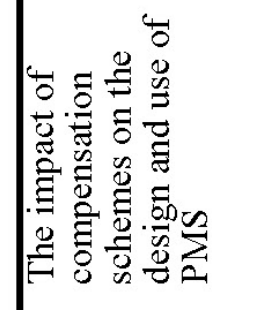 & 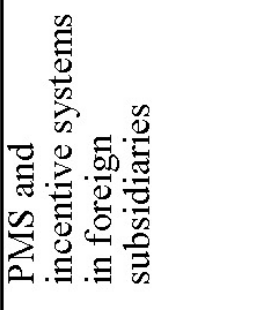 \\
\hline 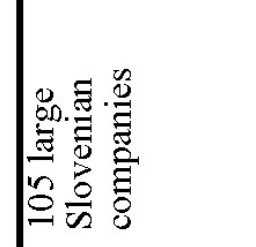 & 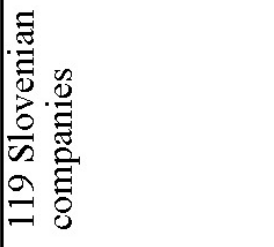 \\
\hline 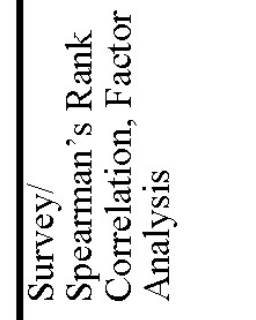 & 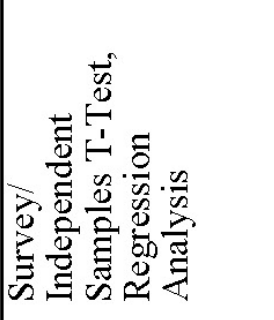 \\
\hline 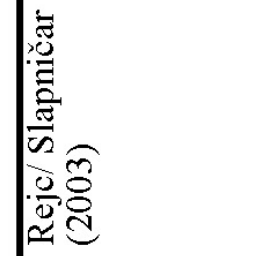 & 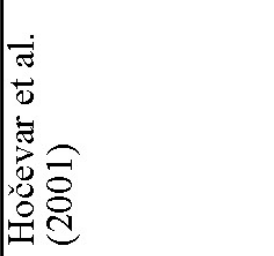 \\
\hline
\end{tabular}




\section{Future research directions}

The preceding review indicates that each of the four determinants of PMS design has been examined to some degree, but significant opportunities exist in each area. First, we highlight specific research opportunities within each of the four determinants of contemporary PMS. Then, we propose some additional research questions along with some thoughts on research methods.

\section{Future research on multidimensionality}

First, it is important to enhance the richness of multidimensionality variables. For example, many existing surveys in CEE countries focus on the Balanced Scorecard as a surrogate for multidimensionality. Additional research should use other, state-of-the art and more comprehensive research tools to investigate PMS used by CEE companies. Various other perspectives may constitute PMS multidimensionality (see, for example, Brignal (2002) critique of the Balanced Scorecard), specifically in other cultural contexts such as CEE, characterized also by different historical and legislative characteristics (for example, see Bollinger 1994; Fogel 1994; Child/Czeglédy 1996; Soulsby/Clark 1996; Malý 2002; Dunkel/Meierewert 2004; Warner et al. 2005).

Second, a thorough analysis is needed on contemporary PMS and their impact on financial performance that reaches beyond that proposed by the North American and the West European theory and practice. Performance measurement in the CEE lacks the critical mass of related studies needed to reconcile conflicting results and reach consensus on the performance benefits of various performance measurement practices.

Third, causality of contemporary PMS multidimensional perspectives should be investigated. Most of contemporary performance measurement frameworks implicitly suggest that there are cause-and-effect relationships between the drivers of various aspects of performance. The Balanced Scorecard, for example, is built around the causal linkages between the drivers of learning and growth, internal processes, customers, and financial perspectives. Specific investigation of temporal relationships between actual actions and performance is needed to see whether these Western frameworks are equally successful in business contexts with different cultural backgrounds.

\section{Future research on PMS strategic alignment}

Further research is needed to better understand why PMS in CEE countries are not as closely aligned with company strategies as theory suggests. More specifically, additional research should engage in assessing management accounting and management control expertise in evaluating the types of knowledge and abilities needed by managers. For example, research could address whether a manager's overall experience and tenure affect the strategic 
focus of PMS. Experimental research involving manager expertise could be used to supplement the extant survey literature.

Second, we encourage research on the nature of traditions and values fostered by the CEE managers and how these impact their decision-making and use of strategic information. Several studies highlight specific strategic orientations of CEE managers, such as maintaining employment and strategy of survival (Malý 2002), short-term orientation (Horváth et al. 2008), strong relationships with the local communities (Warner et al. 2005) etc.

Third, we highlight the need for research on other factors that are associated with the quality of information provided to managers, such as professional knowledge of accountants, the quality of management information systems etc.

Finally, it is of particular interest to reveal whether the ability to attract young, knowledgeable, and flexible managers (capable of introducing and using contemporary PMS) varies with company characteristics such as size, industry, and proxies for agency costs.

\section{Future research on PMS cascading}

The relative paucity of research on PMS cascading in CEE countries is probably due in large part to the methodological challenges associated with measuring and assessing the construct. Cascading is difficult to observe directly, because one needs to disentangle the aggregate information at the upper hierarchical levels to individual drivers of this information at lower hierarchical levels. Further, understanding the cause-and-effect relationships between the various drivers of success among different hierarchical levels in the organization is needed to set up (or investigate) a proper cascaded system of information. In addition, examination of cascading requires comprehensive studies of multibusiness companies with units of investigation coming from all hierarchical levels. Despite these methodological and resource-related issues, we highlight the need to assess the role of PMS cascading in enhancing the effectiveness of contemporary PMS.

The study by Bodnár and Dobák (1998) found that the application of a contemporary PMS was limited to a single organizational unit. Further research is needed to investigate what organizational and other obstacles (such as the lack of top management commitment, conflicting interests of managers at different hierarchical levels, management information systems etc.) inhibit the proliferation of contemporary PMS throughout the organization.

\section{Future research on PMS alignment with incentive systems}

First, we highlight the need for research on factors that are associated with the development of incentive systems in CEE countries. Several authors describe the prevailing egalitarianism among workers (and managers), worker selfmanagement, and the power of workers and labour unions in centrally planned 
economies (Stanojević 2001; 2004; Otte 2003; Rejc 2004; Warner et al. 2005). We suggest the need to investigate whether these factors still play such a strong role in determining performance criteria and whether they inhibit the development of contemporary incentive systems.

Second, we suggest innovative research methods to further investigate this challenging area. For example, analytical modelling could be useful in developing a CEE-country-specific theory related to manager incentives under different reward (compensation) and penalty (legal liability) schemes. More specifically, research is needed to investigate which performance indicators are applied in management compensation contracts in the CEE countries, whether they are aligned with PMS, what is the proportion of the CEO's variable compensation, and how this alignment is instrumental in enhancing company performance. Alternatively, experimental markets lend themselves to the use of alternative subject groups (such as CEE students) in tightly controlled laboratory settings. Such experiments could be used to provide useful insights into the role of various performance variables (for example, financial vs. non-financial performance measures of success) as criteria for financial incentives.

\section{Overall discussion on future research}

From an overall perspective, future research should also be directed at the following: firstly, understanding of the role of contemporary PMS in enhancing firm profitability could be improved considerably by investigating the interaction among the four determinants of contemporary PMS. Research questions addressed in these studies should include questions regarding how multidimensionality variables interact with strategic focus variables and how they align with incentive systems variables. In addition, further research is needed to confirm the impact of multidimensionality, strategic focus, cascading, and the alignment between PMS and incentive systems on PMS effectiveness. Very few studies in CEE have addressed this question (Epstein et al. 2004; Rejc Buhovac/Slapničar 2007), and even these have been qualitative, case studybased. Additional (quantitative) research is needed to explore the interrelatedness of these issues.

Secondly, a large number of authors (Čadež 2002; Szychta 2002; Haldma/Lääts 2002; Pärl 2006; Wagner et al. 2007; Zoltay Paprika et al. 2008) reported the lack of appropriate management accounting knowledge as a factor holding back the development and use of contemporary performance measurement systems. Other studies report on the lack of general management skills and knowledge (Vámosi 2000; Slávik 2001) that goes back to the management formation and development practices germane to the CEE area (see also other studies, e. g. Child/Czeglédy 1996; Djankov/Pohl 1998; Pučko 1998; Edwards/Lawrence 2000; Robinson/Tomczak-Stepien 2000; Illes/Rees 2001; King et al. 2001; Kozarzewski 2001; Warner et al. 2005). Specific issues of interest include (a) 
whether management accounting and management control knowledge and skills differ across countries and cultures; (b) how have these knowledge and skills changed in the last ten years; and (c) whether improvements in this area influence the performance measurement systems at their companies.

Thirdly, empirical research still fails to build on prior studies to increase the understanding of the topic. Only a couple of studies use the longitudinal approach or build on prior research (Epstein et al. 2004; Rejc Buhovac/Slapničar 2007; Bodnár et al. 2007; Zoltay Paprika et al. 2008).

Fourthly, we also underline the need to assess the generalizability of research findings. For example, future research is needed to study whether countryspecific findings are applicable to the CEE region as a whole. Most of the studies included in this paper focus on a single CEE country (the only exception being the study of the Czech Republic, Estonia, and Hungary by Horváth et al. 2008). A cross-country or worldwide comparative research project is needed to assist in: 1) providing a comprehensive review of prevailing contemporary performance measurement practices; 2) offering statistically supported arguments of the impact of PMS on financial performance; 3) pointing out country-specific factors of contemporary performance measurement systems in the CEE region; and 4) providing relevant information needed for comparison of PMS practices in the CEE region with those in the North America and Western Europe.

In addition, along with the suggestion to improve the scientific rigor of existing research, alternative research methods should be considered to triangulate the literature and provide new theoretical and practical insights to enhance the role of contemporary PMS. Our review indicates the relative dominance of survey methods. Analytical modelling and (psychology-based) experiments could be used to gain useful insights into the role of various PMS determinants in enhancing the profitability of firms.

Finally, additional research is needed to investigate the differences between companies that are still owned by governments and influenced by political interests, companies that belong to multinational corporations (where the parent company likely determines the development and implementation of PMS), and companies owned by domestic investors. Such research could expand the current understanding of how ownership determines the use of contemporary tools (Cox et al. 1998; Gregorič et al. 2000; Pučko 2005; Warner et al. 2005).

\section{Implications for managers}

It is important to denote that the literature review presented in this paper should be considered a review of academic literature rather than a review of prevailing management practices in CEE countries. In spite of this, the study offers several managerial implications for both, the companies which are not from one of the 
CEE countries and which are considering a launch of activities in CEE countries, as well as the companies or managers of CEE-origin.

First, although evidence has been provided that performance measurement practices in CEE countries lag behind their Western counterparts, there is also apparent evidence of a transition from a predominant reliance on financial measures toward the use of balanced PMS. Integrated, multidimensional PMS have been found particularly useful in larger organizational settings where management control is a complex challenge. For SMEs, the development of contemporary PMS is rare and expectedly conditioned by available resources (and managerial knowledge). In both cases, the deployment of contemporary multidimensional PMS depends heavily on the accounting and management control knowledge of managers and other decision-makers. It is of highest importance for both foreign companies operating in CEE countries (or considering the launch of operations in this region) as well as for domestic ones, that the knowledge-related problem is properly addressed and that management training and education in the field of contemporary management control are provided.

Second, CEE studies confirmed that multidimensional and balanced performance measurement will not lead to increased financial performance if not cascaded and aligned to compensation systems. However, there is another obstacle to effective implementation of PMS systems germane to the CEE region. The average variable part of a CEO's compensation typically amounts to only $15 \%$ of the total (see, for example, Otte 2003; Rejc/Slapničar 2003). When the potential size of exercises under compensation plan arrangements is small relative to that of basic salaries, and benefits in particular, then the achievement of compensation scheme targets is unlikely to act as a powerful influence on executive priorities. As a consequence, the relatively small performancedependent part of CEO compensation schemes may act as an additional barrier to a positive impact of aligned performance measurement and incentive systems on financial performance. With this in mind, companies operating (or planning to operate) in CEE countries need to consider redesigning management compensation contracts.

Finally, it is important to emphasize that replication of Western practices is not considered the best solution to the evolution of contemporary PMS in CEE. As Child and Czeglédy (1996) put it, "a specific set of culturally-generated efficiency values in economic decision making" is one of the characteristics of a model of market perfection. It is by no means clear that this system is best suited to countries which do not share the individualistic cultural paradigm of the Anglo-Saxon countries. Individual CEE countries need to build on existing performance criteria in order to create performance measurement practices in tune with their social and cultural environment as not all practices admired abroad are necessarily appropriate, nor do they fit culturally with local practices. 
Individual national cultures may be in fact better aligned with different models of management formation and, consequently, performance measurement.

\section{Conclusions}

The paper investigates the current status of performance measurement systems research in Central and Eastern Europe. It exposes the most important empirical findings from the previous research in a single study and underlines those areas of research that have been neglected or under-examined. It specifically suggests what future research needs to be done from the perspective of PMS multidimensionality, strategic alignment, cascading, and alignment of PMS with incentive systems, as well as from an overall perspective.

The literature review indicates that each of the four determinants of PMS design has been examined to some degree, but also that significant opportunities exist in each area to gain a better understanding of PMS effectiveness. Extant literature typically focuses on either one country or, and this is rather rare, presents empirical comparisons based on a few selected countries. In addition, the focus of most existing studies is on selected performance measurement issues. This paper upgrades the existing literature by offering a comprehensive overview of all empirical research on contemporary PMS in CEE countries in a single study and by providing a synthesis of research findings useful for foreign and CEE managers.

The paper has limitations, too. For example, although a number of researchers have studied the characteristics of performance measurement systems in the $\mathrm{CEE}$, our analysis reveals that only a few contributions of high quality have so far been published in major academic journals. While focusing on wellestablished research conferences from the field, a number of studies included in our review are still either based solely on case studies, or their analyses are limited to descriptive statistics which may compromise the reliability and validity of empirical findings.

Another limitation of the study is related to the absence of information on the ownership structure of sample companies in the empirical papers. In most cases, local subsidiaries of multinational organizations based in North America or Western Europe were not considered as a separate sample or cluster of companies.

Our study is focused on contributions in English language only. Studying papers published in national academic journals or presented at research conferences in local languages might add to a more profound understanding of contemporary performance measurement systems in CEE. Such approach would require an international team of researchers.

Due to these issues, a significant gap might exist between research findings and actual practice in the field of contemporary performance measurement systems. 
In this context, the literature review presented in this paper should be considered as a review of academic literature rather than a review of prevailing management practices in CEE countries.

\section{References}

Abernethy, M.A./ Lillis, A. (1995): The Impact of Manufacturing Flexibility on Management Control System Design, in: Accounting, Organizations and Society, 20, 241-258.

Ahn, H. (2001): Applying the Balanced Scorecard: An Experience Report, in: Long Range Planning, 34, 441-461.

Alas, R./ Zernand, M. (2002): Management in the Central and Eastern European Transition Countries: Estonia, in: Journal for East European Management Studies, 7, 2, 401-409.

Anthony, R.N. (1965): Management Planning and Control Systems: A Framework for Analysis. Boston: Harvard Business School Press.

Anthony, R.N./ Govindarajan, V. (1998): Management Control Systems, $9^{\text {th }}$ ed. Burr Ridge: Irwin McGraw Hill.

Atkinson, A.A./ Waterhouse, J.H./Wells, R.B. (1997): A Stakeholder Approach to Strategic Performance Measurement, in: Sloan Management Review, Spring, 25-37.

Aver, B./ Čadež, S. (2009): Management Accountants' Participation in Strategic Management Processes: A Cross-Industry Comparison, in: Journal for East European Management Studies, 3, 310-322.

Banker, R.D./ Potter, G./ Srinivasan D. (2000): An Empirical Investigation of an Incentive Plan that Includes Nonfinancial Performance Measures, in: The Accounting Review, $75,1,65-92$.

Baraldi, S./ Monolo, G. (2004): Performance Measurement in Italian Hospitals: The Role of the Balanced Scorecard, Proceedings of the $4^{\text {th }}$ International Conference on Performance Measurement and Management - PMA 2004, Boston. Cranfield: Center for Business Performance, pp. 75-82.

Bescos, P.L./ Cauvin, E. (2004): Performance Measurement in French Companies: An Empirical Study, in: Epstein, M.J./Manzoni, J.F. (eds.): Performance Measurement and Management Control: Superior Organizational Performance, Studies in Managerial and Financial Accounting, Volume 14, Amsterdam: Elsevier, 185-202.

Bodnár, V./ Dobák, M. (1998): What Use Has It Anyway? An Empirical Analysis on the Use of Performance Indicators and Performance Measurement Tools in Hungary, Proceedings of the Conference Performance Measurement - Theory and Practice, University of Cambridge: Centre for Business Performance.

Bodnár, V./ Dankó, D./ Kiss, N./ Vas, G. (2007): Changes in the Management Control Toolkit of Hungarian Organizations $(1996-2006)$ ', $4^{\text {th }}$ Conference On Performance Measurement And Management Control, Nice, September 26-28, 2007.

Bodnár, V./ Harangozó, T./ Szücs, N./ Dankó, D. (2009): Changes in the Management Control Toolkit of Hungarian Organizations $(1996-2006)$ ', $5^{\text {th }}$ Conference On Performance Measurement And Management Control, Nice, September 23-25, 2009.

Bollinger, D. (1994): The Four Cornerstones and Three Pillars in the 'House of Russia' Management System, in: Journal of Management Development, 13, 49-54. 
Bontis, N./ Dragonetti, N.C./ Jacobsen, K./ Roos, G. (1999): The Knowledge Toolbox: A Review of the Tools Available to Measure and Manage Intangible Resources, in: European Management Journal, 17, 4, 391-402.

Braam, G./ Nijssen, E. (2004): Performance Effects of Using the BSC: A Note on the Dutch Experience, in: Long Range Planning, 37, 4, 335-349.

Bratnicki, M./ Kulikowska, M./ Pietrzyk, M. (2009): Managerial Control, Organizational Entrepreneurship and Performance: An Integrative Framework, Empirical Test, $5^{\text {th }}$ Conference On Performance Measurement And Management Control, Nice, September 23-25, 2009.

Brignall, S. (2002): The Unbalanced Scorecard: A Social and Environmental Critique. Proceedings from the $3^{\text {rd }}$ International Conference on Performance Measurement and Management: Research and Action. Boston, MA, 17-19 July, 85-92.

Bruns, W.J. (ed.) (1992): Performance Measurement, Evaluation, and Incentives. Boston: Harvard Business School Press.

Butler, A./ Letza, S. R./Neale, B. (1997): Linking the Balanced Scorecard to Strategy, in Long Range Planning, 30, 2, 242-253.

Child, J./ Czeglédy, A.P. (1996): Managerial Learning in the Transformation of Eastern Europe: Some Key Issues, in: Organization Studies, 17, 2, 167-179.

Chenhall, R.H. (1997): Reliance on Manufacturing Performance Measures, Total Quality Management and Organizational Performance, in: Management Accounting Research, 8, 187-206.

Chenhall, R.H. (2005): Integrative Strategic Performance Measurement Systems, Strategic Alignment of Manufacturing, Learning and Strategic Outcomes: An Exploratory Study, in: Accounting, Organizations and Society, 30, 395-422.

Clark, E. (2000): Enterprise Restructuring in Local Czech Economies: Management Motive, Organizational Response, and Emergent Economic Forms, in: Edwards, V. (ed.): Proceedings of the $6^{\text {th }}$ Annual Conference on Corporate and Organizational Restructuring, Chalfont St Giles: CREEB, 162-192.

Cox, T./ Hooley, G./ Fahy, J./ Beracs, J./ Fonfara, K./ Snoj, B. (1998): Privatization Method Effect on Performance and Market Orientation of Central/Eastern European Companies, in: Journal for East European Management Studies, 3, 4, 355-371.

Cadež, S. (2002): Strategic Management Accounting: Conceptual Framework and Empirical Evidence from Slovenian Companies, in: Economic and Business Review, 4, 2, 129 157.

Čadež, S./ Guilding, C. (2008): An Exploratory Investigation of an Integrated Contingency Model of Strategic Management Accounting, in: Accounting, Organizations and Society, 33, 836-863.

Datar, S./ Cohen Kulp, S./ Lambert, R.A. (2001): Balancing Performance Measures, in: Journal of Accounting Research, 39, 1, 75-92.

Davis, S./ Albright, T. (2004): An Investigation of the Effect of Balanced Scorecard Implementation on Financial Performance, in: Management Accounting Research, 15, $2,135-153$. 
De Geuser, F./ Mooraj, S./ Oyon, D. (2009): Does the Balanced Scorecard Add Value? Empirical Evidence on Its Effect on Performance, in: European Accounting Review, $18,1,93-122$.

Djankov, S./ Pohl, G. (1998): The Restructuring of Large Companies in the Slovak Republic, in: The Economics of Transition, 6, 1, 67-85.

Dunkel, A./ Meierewert, S. (2004): Culture Standards and Their Impact on Teamwork - An Empirical Analysis of Austrian, German, Hungarian and Spanish Culture Differences, in: Journal for East European Management Studies, 9, 2, 147-174.

Eccles, R.G. (1991): The Performance Measurement Manifesto, in: Harvard Business Review, January/February, 131-137.

Edwards, V./ Lawrence, P.A. (2000): Management in Eastern Europe. Basingstoke: Macmillan.

Epstein, M.J./ Birchard, B. (1999): Counting What Counts: Turning Corporate Accountability to Competitive Advantage. Reading: Perseus Books.

Epstein, M.J./ Manzoni, J.-F. (1998): Implementing Corporate Strategy: From Tableaux de Bord to Balanced Scorecards, in: European Management Journal, 16, 2, 190-203.

Epstein, M.J./ Rejc, A./ Slapničar, S. (2004): The Impact of Performance Measurement on Corporate Financial Performance, Proceedings of the $4^{\text {th }}$ International Conference on Performance Measurement and Management - PMA 2004, Edinburgh. Cranfield: Center for Business Performance, 339-346.

Fawcett, S./ Smith, S./ Cooper, M. (1997): Strategic Intent, Measurement Capability, and Operational Success: Making the Connection, in: International Journal of Physical Distribution \& Logistics Management, 27, 7, 410-421.

Feltham, G.A./ Xie, J. (1994): Performance Measures Congruity and Diversity in Multi-task Principal/Agent Relations, in: The Accounting Review, 69, 429-453.

Fisher, J. (1992): Use of Non-financial Performance Measures, in: Journal of Cost Management, Spring, 31-38.

Fitzgerald, L./ Johnston, R./ Brignall, T.J./ Silvestro, R./ Voss, C. (1991): Performance Measurement in Service Businesses. London: The Chartered Institute of Management Accountants.

Flamholtz, E.G. (1996): Effective Organizational Control: A Framework, Applications and Implications, in: European Management Journal, 14, 6, 596-611.

Fogel, D.S. (1994): Lessons Learned, in: Fogel D.S. (ed.): Managing in Emerging Market Economies: Cases from the Czech and Slovak Republics, 225-233, Boulder, CO: Westview Press.

Frigo, M. (2002): Trends in Strategic Performance Measurement, in: Perspectives on Performance, 2, 1, 14-15.

Frigo, M.L./ Krumwiede, K.R. (1999): Balanced Scorecards: A Rising Trend in Strategic Performance Measurement, in: Journal of Strategic Performance Measurement, 3, February/March, 42-48.

Garrison, R.H. (1990): Managerial Accounting: Concepts for Planning, Control, Decision Making. $6^{\text {th }}$ ed. Homewood: Irwin. 
Gehrke, I./ Horvath, P. (2002): Implementation of Performance Measurement: A Comparative Study of French and German Organizations, in: Epstein M.J./Manzoni J.-F. (eds.): Studies in Managerial and Financial Accounting, 12, Oxford: JAI Press/Elsevier, 159180.

Gersbach, H. (1998): On the Equivalence of General and Specific Control in Organizations, in: Management Science, May, 730-737.

Goold, M./ Quinn, J.J. (1990): The Paradox of Strategic Controls, in: Strategic Management Journal, 43-57.

Govindarajan, V./ Gupta, A.K. (1985): Linking Control Systems to Business Unit Strategy: Impact on Performance, in: Accounting, Organizations and Society, 10, 125-135.

Govindarajan, V./ Shank, J.K. (1995): Strategic Cost Management: Tailoring Controls to Strategies, in: Reeve J.M. (ed.): Readings and Issues in Cost Management, 73-90, New York: Warren, Gorham and Lamont.

Gregorič, A./ Prašnikar, J./ Ribnikar, I. (2000): Corporate Governance in Transitional Economies: The Case of Slovenia, in: Economic and Business Review, 2, 3, 183-207.

Haldma T./ Lääts K. (2002): Contingencies Influencing the Management Accounting Practices of Estonian Manufacturing Companies, in: Management Accounting Research, 13, 4, 379-400.

Hartmann, F.G.H. (2005): The Use and Effects of Accounting Performance Measures under Uncertainty: New Theory and New Evidence, Working paper, RSM-Erasmus University.

Hočevar, M./ Zaman, M./ Čadež, S. (2001): Accounting Information for Managerial Decisionmaking: The Case of Slovenian Companies in the Markets of Former Yugoslavia, in: Economic and Business Review, 3, 3-4, 249-270.

Holmstrom, B./ Milgrom, P. (1991): Multitask Principal-Agent Analyses: Incentive Contracts, Asset Ownership and Job Design, in: Journal of Law, Economics, \& Organization, 7, special Issue, 24-52.

Horváth, P./ Arnaout, A./ Gleich, R./ Seidenschwarz, W./ Stoi, R. (1999): Neue Instrumente in der deutschen Unternehmenspraxis - Berich über die Stuttgarter Studie, in: Egger A./ Grün O./Moser R. (eds.): Managementinstrumente und -konzepte, Entstehung, Verbreitung und Bedeutung für die Betriebswirtschaftslehre, 289-328.

Horváth, P./ Dobák, M./ Haldma, T./ Král, B./ Bodnár, V./ Isensee, J./ Révész, E./ Polyák, C./ Wagner, J. (2008): Central and Eastern European Performance Panel (CEEPP), Research Report, Péter Horváth Stiftung.

Illes, K./ Rees, B. (2001): Developing Competent Managers: the 'Shadow' of Hungarian History, in: Journal for East European Management Studies, 6, 4, 421-443.

Ittner, C.D./ Larcker, D.F. (1995): Total Quality Management and the Choice of Information and Reward Systems, in: Journal of Accounting Research, 33, 1-34.

Ittner, C.D./ Larcker, D.F. (1997): Quality Strategy, Strategic Control Systems, and Organizational Performance, in: Accounting, Organizations and Society, 22, 2-3, 293 314. 
Ittner, C.D./ Larcker, D.F. (1998): Are Non-financial Measures Leading Indicators of Future Financial Performance? An Analysis of Customer Satisfaction, in: Journal of Accounting Research, 36, 1-35.

Ittner, C.D./ Larcker, D.F./ Rajan, M.V. (1997): The Choice of Performance Measures in Annual Bonus Contracts, in: The Accounting Review, 72, 2, 231-255.

Ittner, C.D./ Larcker, D.F./ Meyer, M.W. (2003a): Subjectivity and the Weighting of Performance Measures: Evidence from a Balanced Scorecard, The Accounting Review, 78, 3, 725-758.

Ittner, C.D./ Larcker, D.F./ Randall, T. (2003b): Performance Implications of Strategic Performance Measurement in Financial Services Firms, in: Accounting, Organizations, and Society, 28, 7, 715-741.

Jaruga, A./ Ho, S.S.M. (2002): Management Accounting in Transitional Economies. Management Accounting Research, 13, 375-378.

Kaplan, R.S./ Norton, D.P. (1996): The Balanced Scorecard: Translating Strategy Into Action. Boston: Harvard Business School Press.

Kaplan, R.S./ Norton, D.P. (2001): The Strategy-Focused Organization: How Balanced Scorecard Companies Thrive in the New Business Environment. Boston: Harvard Business School Press.

Kaplan, R.S./ Norton, D.P. (2004): Strategy Maps: Converting Intangible Assets into Tangible Outcomes. Boston: Harvard Business School Press.

Kaynak, H. (2003): The Relationship between Total Quality Management Practices and Their Effects on Firm Performance, in: Journal of Operations Management, 21, 405-435.

Keegan, D.P./ Eiler, R.G./ Jones, C.R. (1989): Are Your Performance Measures Obsolete?, in: Management Accounting, 70, 12, 45-50.

Kennerley, M.P./ Neely, A.D. (2000): Performance Measurement Frameworks: A Review, Proceedings of the $2^{\text {nd }}$ International Conference on Performance Measurement, Cambridge, 291-298.

King, N./ Beattie, A./ Cristescu, A.M. (2001): Developing Accounting and Audit in a Transition Economy: the Romanian Experience, in: The European Accounting Review, 10, 1, 149-171.

Kohn, A. (1993): Punished by Rewards: The Trouble with Gold Stars, Incentive Plans, A's, Praise, and Other Bribes. Boston: Houghton Mifflin.

Kozarzewski, P. (2001): Corporate Governance Restructuring in the Course of Privatization in Poland, Proceedings of the $3^{\text {rd }}$ International Conference on Enterprise in Transition, Split-Hvar, May 24-26. Split: Faculty of Economics, 2053-2074.

Král, B./ Matyáš O./ Menšik M./ Šoljaková L./ Stránský J./ Wagner J. (2007): Management Accounting for Strategic Control in the Czech Republic: Tradition or Challenge? Empirical Study, 30th Annual Congress European Accounting Association, Lisbon: European Accounting Association.

Lascu, D./ Manrai, L./ Manrai, A./ Kleczek R. (2006): Interfunctional Dynamics and Firm Performance - A Comparison Between Companies in Poland and the United States, in: International Business Review, 15, 641-659.

Latest Trends in Corporate Performance Measurement (2002): Technical Briefing, CIMA. 
Letza, S.R. (1996): The Design and Implementation of the Balanced Business Scorecard: An Analysis of Three Companies in Practice, in: Business Process Management Journal, $2,3,54-76$.

Liang, C.-J./ Hou, L.-C. (2006): A Dynamic Connection of Balanced Scorecard Applied for the Hotel, in: Journal of Services Research, 6, 2, 91-118.

Lipe, M.G/ Salterio, S.E. (2000): The Balanced Scorecard: Judgmental Effects of Common and Unique Performance Measures, in: The Accounting Review, 75, 3, 283-298.

Llaci, S./ Kume, V./ Leskaj, B. (2002): Business and Management in Albania, in: Journal for East European Management Studies, 7, 4, 416-427.

Lynch, R./ Cross, K. (1991): Measure up! Yardsticks for Continuous Improvement. Cambridge: Basil Blackwell.

Malý, M. (2002): Managerial Changes in Transition: Case of the Czech Republic, in: Journal for East European Management Studies, 7, 4, 410-415.

Marc, M./ Peljhan, D./ Ponikvar, N./ Šobota, A./ Tekavčič, M. (2010a): Performance Measurement in Large Slovenian Companies, International Journal of Management and Information Systems, 14, 5, 129-139.

Marc, M./ Peljhan, D./ Ponikvar, N./ Šobota, A./ Tekavčič, M. (2010b): Determinants of Integrated Performance Measurement Systems Usage: An Empirical Study, in: Journal of Applied Business Research, 26, 5, 63-75.

Merchant, K.A. (1989): Rewarding Results: Motivating Profit Center Managers. Boston: Harvard Business School Press.

Merchant, K.A./ Bruns, W.J. Jr. (1986): Measurements to Cure Management Myopia, in: Business Horizons, 29, 3, 56-64.

Neely, A.D./ Adams, C./ Crowe, P. (2001): The Performance Prism in Practice, Measuring Business Excellence, 5, 2, 6-14.

Nørreklit, H. (2000): The Balance on the Balanced Scorecard: A Critical Analysis of Some of Its Assumptions, in: Management Accounting Research, 11, 1, 65-88.

Nørreklit, H. (2003): The Balanced Scorecard: What Is the Score? A Rhetorical Analysis of the Balanced Scorecard, in: Accounting, Organizations and Society, 28, 591-619.

OECD List of CEE Countries (2010). http://www.oecd.org/

Otley, D.T./ Berry, A. (1994): Case Study Research in Management Accounting and Control, in: Management Accounting Research, 5, 45-65.

Otley, D.T./ Broadbent, J./ Berry, A. (1995): Research in Management Control: An Overview of Its Development, in: British Journal of Management, 6, Special Issue, 31-44.

Otte, T. (2003): Compensation Management in Poland, in: Journal for East European Management Studies, 8, 2, 149-172.

Papalexandris, A./ Ioannou, G./ Prastacos, G. (2004): Implementing the BSC in Greece: A Software Firm's Experience, in: Long Range Planning, 37, 4, 351-366.

Pärl, Ü. (2006): Choice of Measures for Performance Measurement Models on the Example of Successful Estonian Companies, in: Pärl, Ü. (ed.): Entrepreneurship in Estonia: Policies, Practices, Education and Research, 228-247. 
Peljhan, D./ Tekavčič, M./Marc, M./Šobota, A. (2009): Performance Measurement Progress in Slovenian Companies: An Empirical Study, $5^{\text {th }}$ Conference on Performance Measurement and Management Control, Nice, France, September 23-25, 2009.

Perera, S./ Harrison, G./Pole, M. (1997): Customer-focused Manufacturing Strategy and the Use of Operations-based Non-financial Performance Measures: A Research Note, in: Accounting, Organizations and Society, 22, 557-572.

Pučko, D. (1998): Researching Management in Central and Eastern Europe: Researcher, Manager, and Management Practice - Comment and Views, in: Journal for East European Management Studies, 3, 3, 390-393.

Pučko, D. (2005): Corporate Governance in European Transition Economies: Emerging Models, in: Management, 10, 1, 1-21.

Pučko, D./ Čater, T. (2008): A Holistic Strategy Implementation Model Based on the Experiences of Slovenian Companies, in: Economic and Business Review, 10, 4, $307-$ 325.

Rejc, A. (2003): Traditional vs. Contemporary Performance Measurement: Evidence from Large Slovenian Companies, in: Economic and Business Review, 5, 1-2, 117-135.

Rejc, A. (2004): Toward Contingency Theory of Performance Measurement, in: Journal for East European Management Studies, 9, 3, 243-264.

Rejc, A./ Slapničar, S. (2003): Management Compensation Contracts and Performance Measurement Systems in Large Slovenian Companies. Interdisciplinary Perspectives in Accounting Conference, Madrid.

Rejc, A./ Slapničar, S. (2004): Determinants of Performance Measurement System Design and Corporate Financial Performance, in: Epstein M.J./Manzoni J.F. (eds.): Studies in Managerial and Financial Accounting, Volume 14: Performance Measurement and Management Control: Superior Organizational Performance, 47-73, Oxford: JAI Press/Elsevier.

Rejc Buhovac, A./ Slapničar, S. (2007): The Role of Balanced, Strategic, Cascaded and Aligned Performance Measurement in Enhancing Firm Performance, in: Economic and Business Review, 9, 1, 47-78.

Renko, F./ Pecotich, A. (2001): The Balanced Scorecard as a Possible Key for Improvement of Business Strategy: An Empirical Case from Croatian Banking Industry, Proceedings of the $4^{\text {th }}$ International Conference on Enterprise in Transition, SplitHvar, May 24-26. Split: Faculty of Economics, 871-884.

Robinson, I./ Tomczak-Stepien, B. (2000): Cultural Transformation at Enterprise Level: Case Study Evidence from Poland, in: Journal for East European Management Studies, 3, 2, 130-151.

Said, A.A./ HassabElnaby, H.R./ Wier, B. (2003): An Empirical Investigation of the Performance Consequences of Non-financial Measures, in: Journal of Management Accounting Research, 15, 193-223.

Simons, R. (1990): The Role of Management Control Systems in Creating Competitive Advantage: New Perspectives, in: Accounting, Organizations and Society, 15, 1-2, 127-143.

Simons, R. (1995): Levers of Control: How Managers Use Innovative Control Systems to Drive Strategic Renewal. Boston: Harvard Business School Press. 
Simons, R. (2000): Performance Measurement \& Control Systems for Implementing Strategy. Upper Saddle River: Prentice Hall.

Slávik, Š. (2001): Strategic Management in Slovak Enterprises - Survey Findings, in: Journal for East European Management Studies, 6, 1, 65-91.

Soulsby, A./ Clark, E. (1996): The Emergence of Post-communist Management in the Czech Republic, in: Organizational Studies, 17, 227-247.

Speckbacher, G./ Bischof, J./Pfeiffer, T. (2003): A Descriptive Analysis of the Implementation of Balanced Scorecards in German-Speaking Countries, in: Management Accounting Research, 14, 361-387.

Stanojević, M. (2001): Industrial Relations in 'Post-Communism': Workplace Co-operation in Hungary and Slovenia, in: Journal for East European Management Studies, 6, 4, 400-420.

Stanojević, M. (2004): Production Coalitions in Slovenian Companies: Employee Participation in Non-participative Organizations, in: Journal for East European Management Studies, 9, 3, 225-242.

Symons, R./ Jacobs, R. (1995): A Total Quality Management-based Incentive System Supporting Total Quality Management Implementation, in: Production and Operations Management, 4, 3, 28-41.

Szychta, A. (2002): The Scope of Application of Management Accounting Methods in Polish Enterprises, in: Management Accounting Research, 13, 401-418.

Tonge, R./ Larsen, P./ Pepper, J. (2000): Balanced Scorecards and the FTSE: Exploratory Research, in: International Journal of Performance Management, 2, 4, 293-310.

Vámosi, S.T. (2000): Continuity and Change; Management Accounting During Process of Transition, in: Management Accounting Research, 11, 27-63.

Vitezić, N. (2004): Ownership Structure and Performance Measurement in Transitional

Economy: A Case of Croatia, 20th EGOS Colloquium, Ljubljana, July1-3, www.egosnet.com

Vitezić, N./ Knez-Riedl, J. (2005): The Use of Financial and Non-Financial Measures in Decision-Making Process of Enterprises' Performance in a Transition Economy, 6th International Conference Enterprise in Transition, Split-Bol, May 26-28.

Vrdoljak Raguž, I./ Jelenc, L. (2010): Performance Measurement System in Turbulent Environment: The Case of Large Croatian Enterprises, 5th International Conference 'An Enterprise Odyssey: From Crisis to Prosperity - Challenges for Government and Business', Opatija, May 26-29.

Wagner, J./ Šoljaková, L./ Matyáš, O. (2007): Strategic Performance Measurement and Compensation Systems in the Czech Republic (Empirical Study), in: European Financial and Accounting Journal, 3-4, 8-26.

Warner, M./ Edwards, V./ Polonsky, G./ Pučko, D./ Zhu, Y. (2005): Management in Transitional Economies: From the Berlin Wall to the Great Wall of China. London: Routledge Curzon.

Weber, J./ Schäffer, U. (2001): On the Way to Active Management of Performance Measures, in: International Journal of Business Performance Management, 3, 1, 47-65. 
Zaman, M. (2004): The Role of Financial and Non-Financial Evaluation Measures in the Process of Management Control over Foreign Subsidiaries: Empirical Evidence in Slovene Multinational Companies, in: Management, 9, 2, 53-73.

Zernand-Vilson, M./ Terk, E. (2009): The State and the Dynamics of Management and Organisational Development Indicators in Estonian Enterprises, in: EBS Review, 26, 8-24.

Zoltay Paprika, Z./ Wimmer, A./ Szanto, R. (2008): Managerial Decision Making and Competitiveness: the Case of Hungary, in: Competitiveness Review, 18, 1/2, 154- 167. 